\title{
Fucosterol of Marine Macroalgae: Bioactivity, Safety and Toxicity on Organism
}

\author{
Maria Dyah Nur Meinita $1,2,3, * \mathbb{D}$, Dicky Harwanto ${ }^{1,4}$, Gabriel Tirtawijaya ${ }^{1}$, \\ Bertoka Fajar Surya Perwira Negara ${ }^{1,5}{ }^{\oplus}$, Jae-Hak Sohn ${ }^{1,5}$, Jin-Soo Kim ${ }^{6, *}$ and Jae-Suk Choi $1,5, * \mathbb{B}$ \\ 1 Seafood Research Center, Industry Academy Cooperation Foundation (IACF), Silla University, 606, \\ Advanced Seafood Processing Complex, Wonyang-ro, Amnam-dong, Seo-gu, Busan 49277, Korea; \\ dickyharwanto@lecturer.undip.ac.id (D.H.); ftrnd6@silla.ac.kr (G.T.); ftrnd12@silla.ac.kr (B.F.S.P.N.); \\ jhsohn@silla.ac.kr (J.-H.S.) \\ 2 Faculty of Fisheries and Marine Science, Jenderal Soedirman University, Purwokerto 53123, Indonesia \\ 3 Center for Maritime Bioscience Studies, Jenderal Soedirman University, Purwokerto 53123, Indonesia \\ 4 Faculty of Fisheries and Marine Science, Diponegoro University, Semarang 50275, Indonesia \\ 5 Department of Food Biotechnology, College of Medical and Life Sciences, Silla University, 140, \\ Baegyang-daero 700 beon-gil, Sasang-gu, Busan 46958, Korea \\ 6 Department of Seafood and Aquaculture Science, Gyeongsang National University, 38 Cheong-daegukchi-gil, \\ Tongyeong-si 53064, Korea \\ * Correspondence: maria.meinita@unsoed.ac.id (M.D.N.M.); jinsukim@gnu.ac.kr (J.-S.K.); \\ jsc1008@silla.ac.kr (J.-S.C.); Tel.: +62-281-642-360 (M.D.N.M.); +82-557-729-146 (J.-S.K.); \\ $+82-512-487-789$ (J.-S.C)
}

check for updates

Citation: Meinita, M.D.N.; Harwanto, D.; Tirtawijaya, G.; Negara, B.F.S.P.; Sohn, J.-H.; Kim, J.-S.; Choi, J.-S. Fucosterol of Marine Macroalgae: Bioactivity, Safety and Toxicity on Organism. Mar. Drugs 2021, 19, 545. https://doi.org/ $10.3390 /$ md19100545

Academic Editors: Marco García-Vaquero and Brijesh K. Tiwari

Received: 10 September 2021 Accepted: 24 September 2021 Published: 27 September 2021

Publisher's Note: MDPI stays neutral with regard to jurisdictional claims in published maps and institutional affiliations.

Copyright: (c) 2021 by the authors. Licensee MDPI, Basel, Switzerland. This article is an open access article distributed under the terms and conditions of the Creative Commons Attribution (CC BY) license (https:/ / creativecommons.org/licenses/by/ $4.0 /)$.

\begin{abstract}
Fucosterol (24-ethylidene cholesterol) is a bioactive compound belonging to the sterol group that can be isolated from marine algae. Fucosterol of marine algae exhibits various biological activities including anti-osteoarthritic, anticancer, anti-inflammatory, anti-photoaging, immunomodulatory, hepatoprotective, anti-neurological, antioxidant, algicidal, anti-obesity, and antimicrobial. Numerous studies on fucosterol, mainly focusing on the quantification and characterization of the chemical structure, bioactivities, and health benefits of fucosterol, have been published. However, there is no comprehensive review on safety and toxicity levels of fucosterol of marine algae. This review aims to discuss the bioactivities, safety, and toxicity of fucosterol comprehensively, which is important for the application and development of fucosterol as a bioactive compound in nutraceutical and pharmaceutical industries. We used four online databases to search for literature on fucosterol published between 2002 and 2020. We identified, screened, selected, and analyzed the literature using the Preferred Reporting Items for Systematic Reviews and Meta-Analyses method and identified 43 studies for review. Despite the potential applications of fucosterol, we identified the need to fill certain related research gaps. Fucosterol exhibited low toxicity in animal cell lines, human cell lines, and animals. However, studies on the safety and toxicity of fucosterol at the clinical stage, which are required before fucosterol is developed for the industry, are lacking.
\end{abstract}

Keywords: fucosterol; seaweed; algae; toxicity; in vivo; in vitro

\section{Introduction}

Fucosterol is abundant and one of the dominant sterols in marine macroalgae [1]. The purest form of fucosterol and its potency were first identified and observed in the brown macroalga Fucus vesiculosus by Heilbron et al. [2]. Fucosterol is a stigmasterol bond isomer expressed by the empirical formula $\mathrm{C}_{29} \mathrm{H}_{48} \mathrm{O}$. The fucosterol content in macroalgae ranges from 4 to $95 \%$ of the total phytosterol content [3]. Brown macroalgae contain higher levels of fucosterol than green and red macroalgae. The fucosterol content in brown macroalga Ecklonia radiata ranged between $312.0 \mu \mathrm{g} / \mathrm{g}$ dry weight in leaves and $378.1 \mu \mathrm{g} / \mathrm{g}$ dry weight in stipes (98.6 and $98.9 \%$ of total sterols, respectively) [4]. In the brown macroalgae Himanthalia elongata, Undaria pinnatifida, and Laminaria ochroleuca, fucosterol was observed 
predominantly in $83-97 \%$ of the total sterol content [5]. Fucosterol was also reported to be dominant in Stephanocystis hakodatensis (formerly Cytoseira hakodatensis) and Sargassum fusiforme, which contained $65.9 \%$ and $67 \%$ of fucosterol, respectively [6].

Brown macroalgae are widely used as food and herbal medicine in Southeast Asia and several European countries. In Europe, brown macroalgae have been used to treat goiter and obesity [7]. In East Asia, brown macroalgae from the genera Laminaria, Undaria, and Sargassum (formerly Hizikia) are widely consumed daily and used as herb medicine [8-12]. Hence, the bioactive properties of brown macroalgae have drawn the attention of researchers. Previous studies have investigated fucosterol properties and their potential bioactivities. The antioxidant effect of fucosterol was reported by Lee et al. [13]. Furthermore, Jung et al. [14] investigated the anti-inflammatory properties of fucosterol in LPS-stimulated conditions. Fucosterol has the potential to inhibit particulate-induced inflammation and oxidative stress in the alveolar cell line A549. Through regulation of the FoxO signaling pathway, fucosterol exhibits anti-obesity characteristics by suppressing adipogenesis in 3T3-L1 preadipocytes [15]. In addition, fucosterol protects human neuroblastoma cell line SH-SY5Y cells from amyloid-induced neurotoxicity [16] and affects human lung cancer cells by inducing apoptosis and cell cycle arrest and targeting the Raf/signaling mitogen-activated protein kinase/extracellular-signal-regulated kinase (MEK/ERK) pathway [17]. Based on these studies, fucosterol can potentially be developed for use in nutraceutical and pharmaceutical fields. However, before further developing fucosterol properties, information on the safety and toxicity of fucosterol is required to comprehend the optimum and sustainable benefits of fucosterol as a functional agent. This study reviews the current scientific literature regarding the bioactivity, safety, and toxicity of fucosterol extracted from marine macroalgae. In addition to the bioactivity of fucosterol, we investigated the safety and toxicity of fucosterol in various organisms, including bacteria/fungi, animal cell lines, human cell lines, and animals. Through this review article, we express our hope that the applications of fucosterol from marine algae can be further developed in the nutraceutical and pharmaceutical industries.

\section{Results and Discussion}

Studies on the bioactivity, safety, and toxicity levels of fucosterol from marine macroalgae conducted from 2002 to 2020 were reviewed, and an increasing trend was observed (Figure 1). This indicates that fucosterol has drawn additional research attention in recent years.

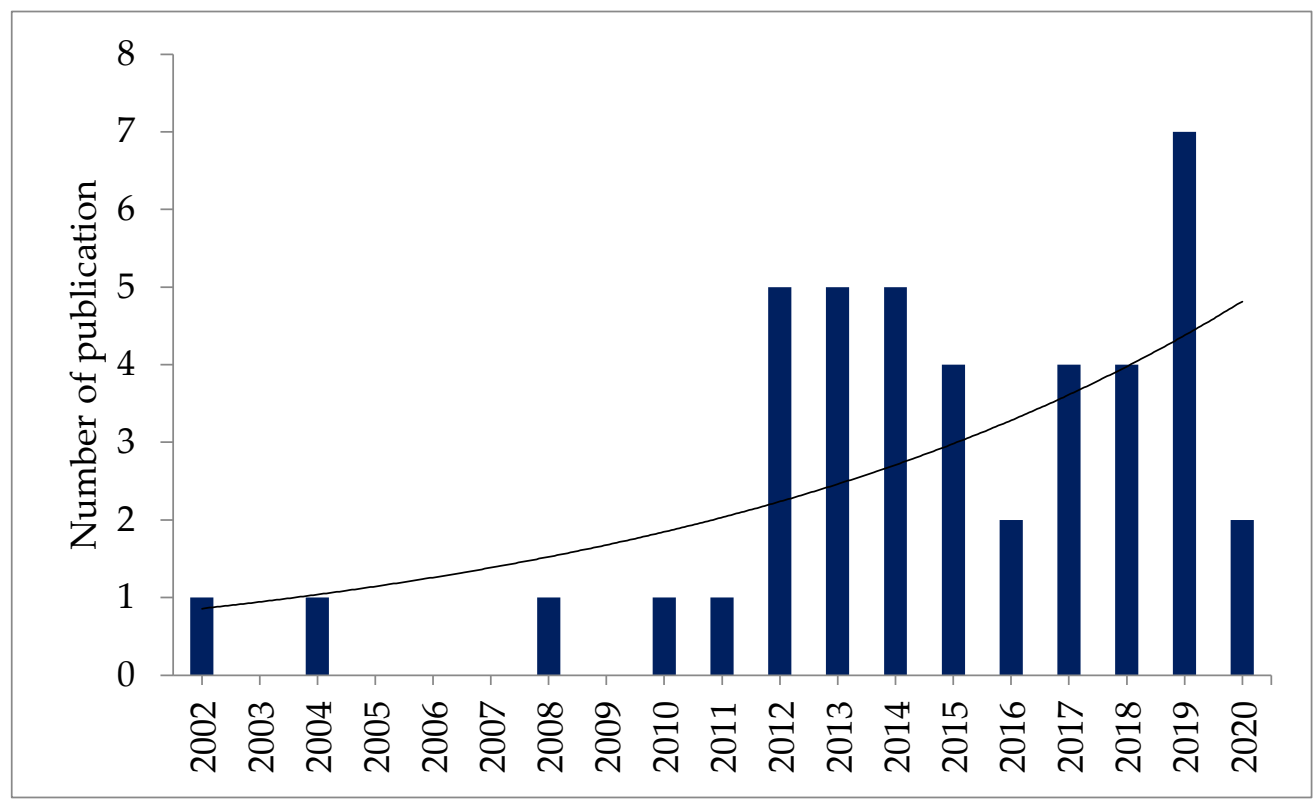

Figure 1. Number of publications on the safety and toxicity of fucosterol published in each year. 
Articles discussing the bioactivity, safety, and toxicity of fucosterol were categorized with respect to the various organisms or cells whose treatment they describe (Figure 2). Published studies on the safety and toxicity of fucosterol from marine algae have focused on its effects on bacteria and fungi (21\%), animal cell lines (14\%), human cell lines (38\%), and animals $(26 \%)$. The safety and toxicity of fucosterol have been studied both in vitro and in vivo. No clinical study of fucosterol has been conducted to date. Therefore, the investigation of the safety and toxicity of fucosterol at the clinical stage might be challenging.

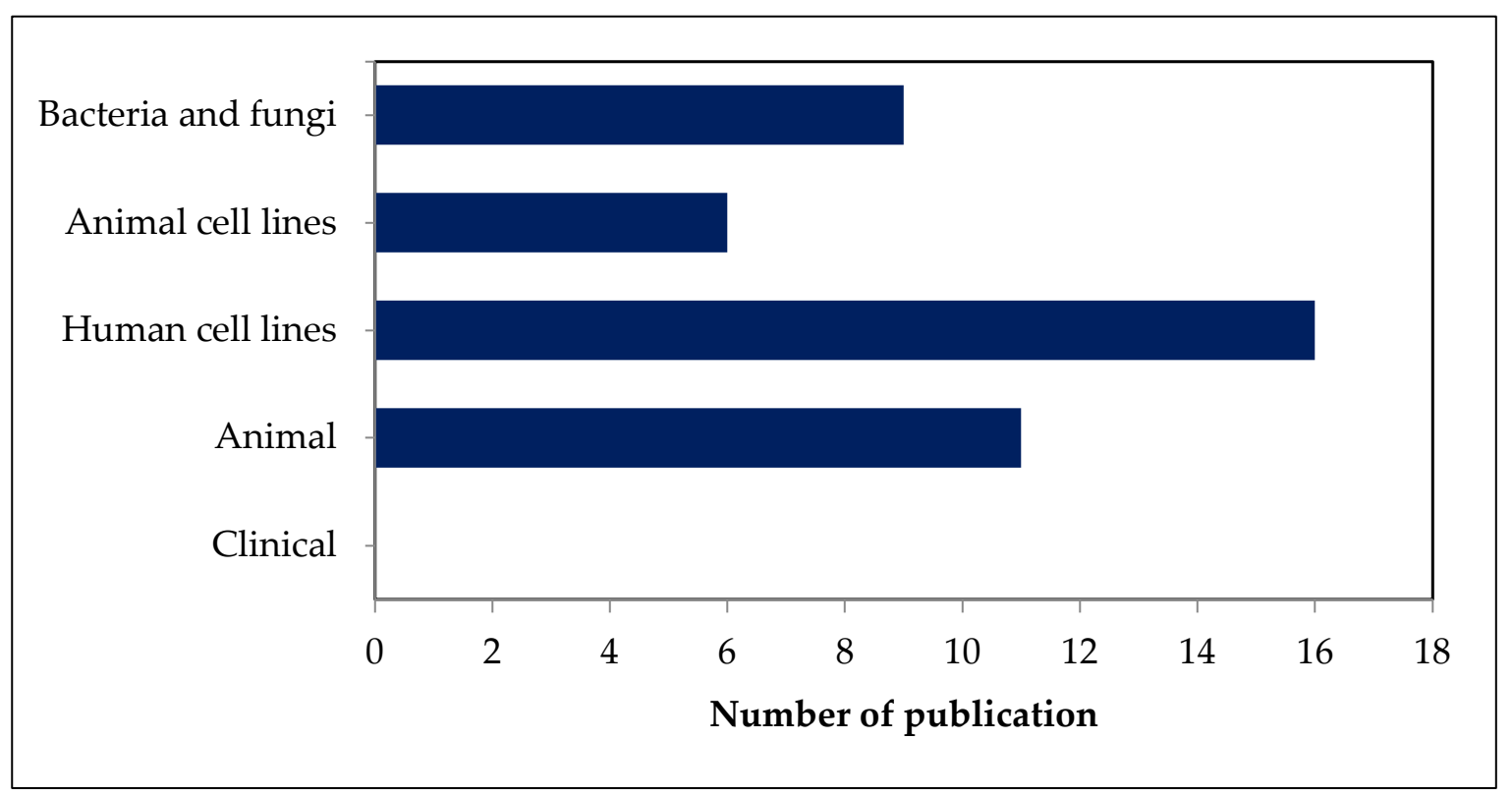

Figure 2. Numbers of publications on safety and toxicity of fucosterol categorized according to the treated organisms or cells.

The numbers of publications on the safety and toxicity of fucosterol from various sources of macroalgae are shown in Figure 3. Sixteen marine algae species belonging to Dictyotaceae, Sargassaceae, Alariaceae, Lessoniaceae, and Fucaceae families have been studied in relation to their fucosterol bioactivity, safety, and toxicity on bacteria, fungi, animal cells, human cells, and animals. Among the 16 marine algae, Sargassum fusiforme (formerly Hizikia fusiformis) has become the greatest marine macroalgal source for fucosterol that has been studied. Over the last 10 years, studies on the bioactivities and nutritional and pharmacological properties of S. fusiforme have increased steadily. Most of the studies on the bioactivity of S. fusiforme have focused on its antioxidant (15.09\%), anticancer and antitumor $(15.09 \%)$, anti-inflammatory $(11.32 \%)$, photoprotective $(11.32 \%)$, and neuroprotective $(11.32 \%)$ properties [18]. Figure 3 shows that the study of fucosterol in S. fusiforme has focused on its antioxidant, anti-osteoarthritic, anti-inflammatory, anti-photoaging, antidiabetic, hepatoprotective, and algicidal effects. Ecklonia cava subsp. stolonifera (formerly Ecklonia stolonifera) is the second most frequently reported macroalgal species that has been studied for its fucosterol content. Ecklonia species have been known as potential source of bioactive compounds [19]. Studies on the safety and toxicity levels of fucosterol obtained from Ecklonia stolonifera were mostly conducted on animal cell lines, human cell lines, and animals. Fucosterol from Ecklonia stolonifera has been studied for its antidiabetic, anti-obesity, anti-neurological, and hepatoprotective effects. The safety and toxicity levels of fucosterol obtained from Ecklonia cava subsp. stolonifera were mostly studied in animals. 


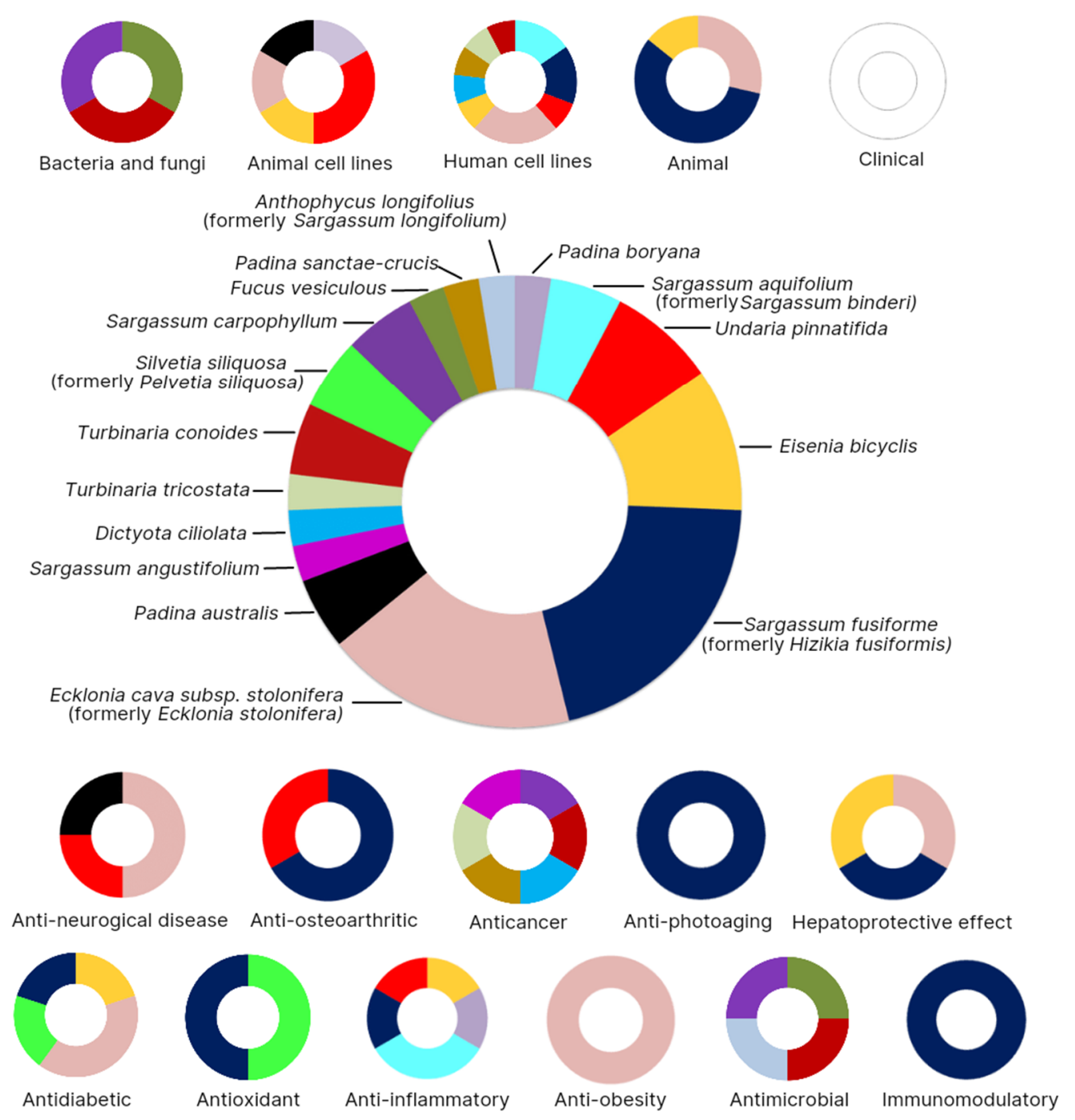

Figure 3. Numbers of publications on safety and toxicity of fucosterol classified according to sources of macroalgae.

\subsection{Characteristics and Structure of Fucosterol}

Generally, fucosterol could be obtained by extracting dry powder of macroalgae using $\mathrm{MeOH}, \mathrm{EtOH}$, or $n$-hexane solvents $[13,20-24]$. The extracts were then partitioned via solvent fractionation $[13,25]$. After solvent dissolution under reduced pressure, the organic extracts were fractionated using silica gel column chromatography with a mixture of solvents of increasing polarity $[14,22,23,26]$. The fraction was eluted using a solvent to remove fatty acids, which were then analyzed further [26].

Currently, fucosterol analysis and identification are carried out using physical properties and spectroscopic methods, including ${ }^{1} \mathrm{H}-\mathrm{NMR}$ and ${ }^{13} \mathrm{C}-\mathrm{NMR}$, as well as via comparison with published data, and thin-layer chromatography (TLC) analysis [20]. According to the molecular formula of fucosterol, one hydroxy group must be attached to C-28 in an $R$ or $S$ configuration. An olefin proton signal and two sets of two olefin signals indicate the presence of a tri-substituted double in the fucosterol side chain [22]. Infrared (IR) absorption peaks of fucosterol at 3400 and $1600 \mathrm{~cm}^{-1}$ were attributed to the hydroxyl and olefin groups, respectively. Fucosterol derivatives, namely $24 R, 28 R$ - and $24 S, 28 R$-epoxy-24ethylcholesterol, and $24 R$-saryngosterol have also been used in octadecyl silica gel (ODS) column chromatography [21]. The structure of fucosterol is shown in Figure 4. 


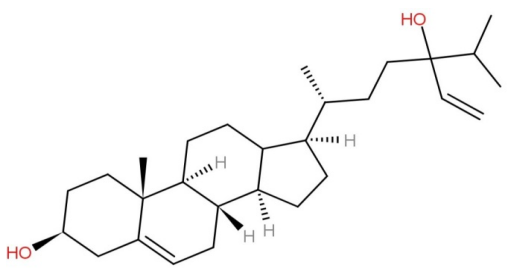

Figure 4. Chemical structure of fucosterol.

\subsection{Bioactivity of Fucosterol}

Fucosterol of marine macroalgae exhibited antidiabetic, anti-obesity, anti-osteoarthritic, immunomodulatory, anticancer, anti-inflammatory, anti-photoaging, hepatoprotective, anti-neurological, antioxidant, and antimicrobial activities (Figure 5).

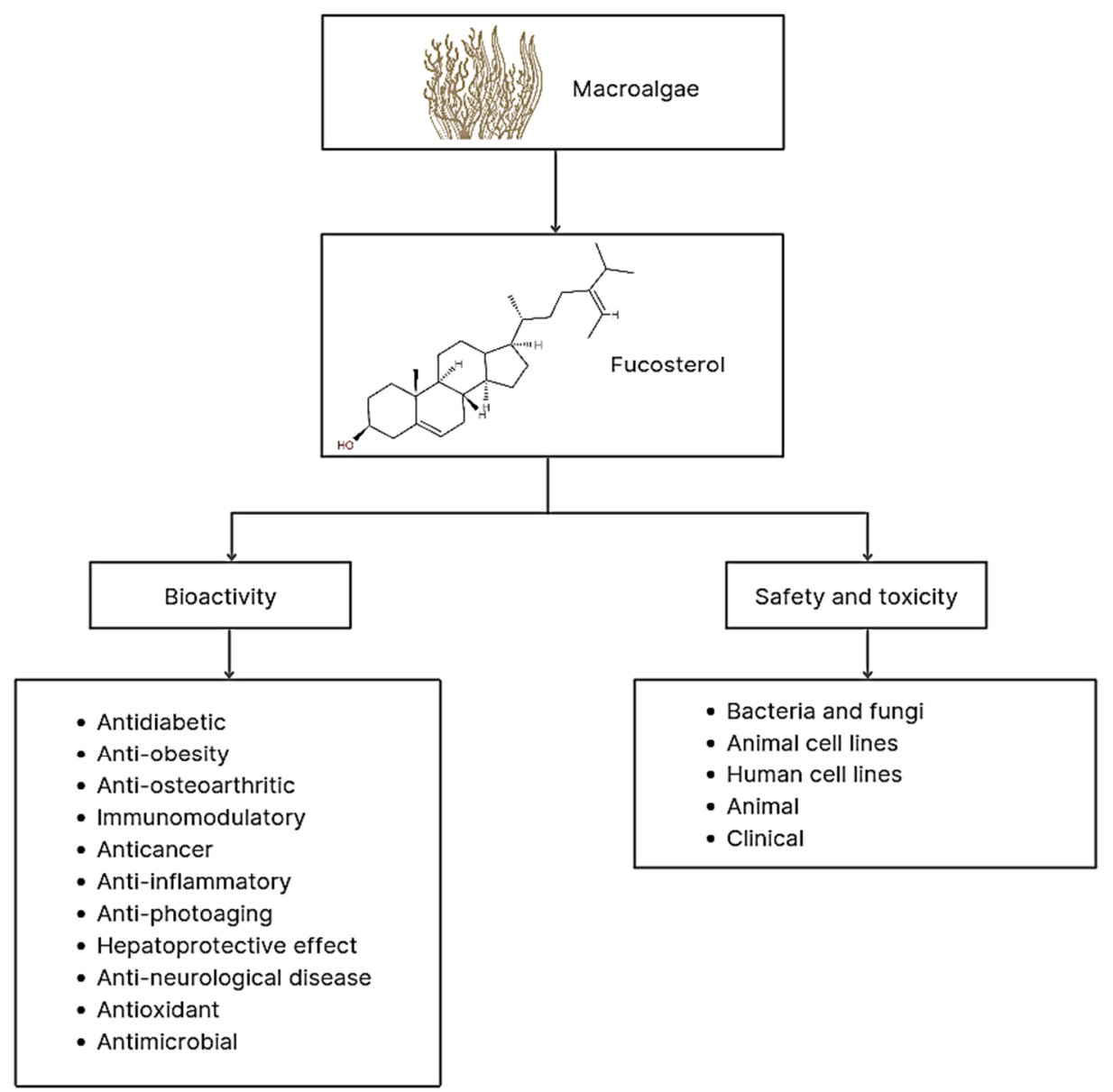

Figure 5. Bioactivities, safety, and toxicity levels of fucosterol derived from macroalgae.

\subsubsection{Antidiabetic Activity}

Diabetes is a chronic disease that occurs when the pancreas does not produce enough insulin or when the body cannot use insulin effectively. One of the antidiabetic effects of fucosterol obtained from Eisenia bicyclis and Ecklonia cava subsp. stolonifera is characterized by inhibition of enzymes, such as rat lens aldose reductase (RLAR), human recombinant aldose reductase (HRAR), $\alpha$-glucosidase, and PTP1B. The docking simulations clearly demonstrated negative binding energy for fucosterol $\left(-8.2 \mathrm{kcal} \mathrm{mol}^{-1}\right.$ for RLAR and $-8.5 \mathrm{kcal} \mathrm{mol}^{-1}$ for HRAR), implying a higher affinity and stronger binding competence for the active site of the enzyme [20]. These results were confirmed by Jung et al. [27], who stated that Ecklonia stolonifera-derived fucosterol reduced insulin 
resistance by decreasing PTP1B expression and activating insulin signaling pathways. Fucosterol from Sargassum fusiforme also showed strong PTP1B inhibition at low concentrations [28]. Streptozotocin-induced diabetic rats treated with fucosterol from Pelvetia siliquosa via an orally administered dose of $30 \mathrm{mg} / \mathrm{kg}$ showed a decrease in serum glucose levels and inhibition of its accumulation. However, orally administered doses of $300 \mathrm{mg} / \mathrm{kg}$ are required for epinephrine-induced diabetic rats to inhibit blood glucose levels and degrade glycogen [29]. These findings illustrate that fucosterol extracts from Eisenia bicyclis, Ecklonia cava subsp. stolonifera, Sargassum fusiforme, and Silvetia siliquosa have antidiabetic potential that can be developed in the future.

\subsubsection{Anti-Obesity Activity}

In addition to being antidiabetic, fucosterol also exhibits anti-adipogenic or antiobesity properties. Adipocytes have important cardiovascular-related roles; therefore, understanding their development and regulation is important for treating obesity and related diseases. Obesity is associated with hypercholesterolemia, diabetes, and other chronic diseases. Hypercholesterolemia is associated with a higher incidence of liver damage, especially non-alcoholic fatty liver disease (NAFLD) [30]. As reported by Jung et al. [25], following treatment with fucosterol extracted from Ecklonia cava subsp. stolonifera, lipid accumulation in 3T3-L1 pre-adipocytes decreased because the expression levels of adipocyte markers, proteins peroxisome proliferator-activated receptor (PPAR), and CCAAT/enhancer-binding protein (C/EBP), decreased [25]. Similar results were reported by Lee et al. [15], who found that fucosterol of Ecklonia cava subsp. stolonifera inhibits adipogenesis of 3T3-L1 preadipocytes via modulation of the FoxO signaling pathway.

\subsubsection{Anti-Osteoarthritis Activity}

The anti-osteoarthritis activity of fucosterol has been demonstrated both in vitro and in vivo [21,31,32]. Anti-osteoarthritis is a biological activity characterized by the ability of a compound to reduce or prevent bone disease. Sargassum fusiforme-derived fucosterol has been shown to increase proliferative activity in osteosarcoma MG63 cells for the treatment of bone-absorbing metabolic bone diseases, including osteoporosis and periodontitis [21]. Similar results were observed in ovariectomized rat osteoporosis and fucosterol of Sargassum fusiforme triggered bone regeneration and activation of bone formation [31], and Bang et al. [32] tested fucosterol in vitro and reported that fucosterol from Undaria pinnatifida inhibited osteoclast differentiation. Through this biological activity, fucosterol may play an important role in preventing osteoporosis and may be useful as a supplement.

\subsubsection{Immunomodulatory Activity}

In immunomodulation, regulating many immune cells through signaling molecules to enhance the immune system, is necessary. Based on previous studies, several marine metabolites have been reported to have regulatory effects on the immune system [33]. Fucosterol is one of the compounds that is regarded as a candidate immunomodulator, as reported by Park et al. [34] in vitro and in vivo; fucosterol from Sargassum fusiforme can increase the secretion of tumor necrosis factor alpha (TNF- $\alpha$ ), NO production, and phagocytosis activity. Generally, fucosterol has the potential to regulate immune function and may offer positive therapeutic effects in immune system diseases.

\subsubsection{Anticancer Properties}

Certain studies about the anticancer properties of fuscosterol extracted from marine macroalgae, such as Sargassum carpophyllum, Turbinaria conoides, Dictyota ciliolata, and Padina sanctae-crucis, have been published [21,35-39]. Based on the study by Jiang et al. [39], commercial fucosterols exhibit anticancer activity by inhibiting the PI3K/Akt/mTOR signaling pathway in cervical cancer cell lines. In addition, fucosterol from Sargassum fusiforme has been observed to slow the progression of human ovarian cancer [35] and inhibit the proliferation of osteosarcoma-derived cell MG63 [21]. Tang et al. [22] isolated 
steroids from Sargassum carpophyllum using activity-guided fractionation to determine the effect of fucosterol and other active substances on cancer cell lines. This activity is indicated by $\mathrm{IC}_{50}$, which is the concentration that results in $50 \%$ inhibition of cell growth [37]. They found that fucosterol has an $\mathrm{IC}_{50}$ value of $7.8 \mu \mathrm{g} / \mathrm{mL}$ against HL-60 cancer cells. A compound can exhibit one of three types of cytotoxicity: (1) potential cytotoxicity, if $\mathrm{IC}_{50}<100 \mu \mathrm{g} / \mathrm{mL}$, (2) moderate cytotoxicity, if $100 \mathrm{~g} / \mathrm{mL}<\mathrm{IC}_{50}<1000 \mu \mathrm{g} / \mathrm{mL}$, and it can be (3) non-toxic, if $\mathrm{IC}_{50}>1000 \mu \mathrm{g} / \mathrm{mL}$. Agents from a group of potentially cytotoxic compounds can be utilized as anticancer drugs, while moderately cytotoxic compounds can be used for chemoprevention to stop cancer cell growth [40]. According to the National Cancer Institute (NCI), a compound is classified as having anticancer properties if its $\mathrm{IC}_{50}$ is $<20 \mu \mathrm{g} / \mathrm{mL}$. Published research studies prove that fucosterol as a metabolite compound in macroalgae has anticancer properties; however, further clinical studies are required.

\subsubsection{Anti-Inflammatory Activity}

Inflammation is a biological response to noxious stimuli. It is a protective response involving immune cells such as macrophages, blood vessels, molecular mediators such as NO, pro-inflammatory cytokines (TNF- $\alpha$, interleukin-1 $\beta$ (IL-1 $\beta$ ), and interleukin-6 (IL-6)), and prostaglandins [41]. Previous studies have identified anti-inflammatory compounds in macroalgae. Fucosterol derived from the methanolic extract of the brown alga Eisenia bicyclis and Undaria pinnatifida exhibits anti-inflammatory properties by suppressing the production of cyclooxygenase-2 (COX-2) and inducible nitric oxide synthase (iNOS) in LPS-stimulated RAW 264.7 macrophages [14,42]. Fucosterol also inhibited t-BHP-induced ROS production and suppressed iNOS and COX-2 expression. Furthermore, E. bicyclis has strong anti-inflammatory properties with the potential to inhibit NO and ROS production, as well as the NF- $\mathrm{BB}$ pathway [14]. Fucosterol from Padina boryana was reported to have anti-inflammatory properties via the regulation of NF- $\mathrm{B} / \mathrm{MAPK}$ and involvement of Nrf2/HO-1 pathways in PM-induced inflammation/oxidative stress in RAW 264.7 macrophage cells [43]. Furthermore, fucosterol extracted from Sargassum aquifolium (formerly Sargassum binderi) decreased ROS levels in PM-induced HaCaT cells and human lung epithelial cells $[15,44]$. Another study also showed inhibition of hypoxia-inducible factor through the PI3K/Akt pathway in keratinocytes (HaCaT) cells induced by cobalt chloride $\left(\mathrm{CoCl}_{2}\right)$. Based on the research conducted, fucosterol from brown macroalgae has the potential to be developed further in the pharmacological field.

\subsubsection{Anti-Photoaging Effect}

Photoaging is a result of chronic ultraviolet irradiation, which is one of the most harmful environmental factors affecting the skin. Recently, studies on marine compounds as safe anti-photoaging alternatives have been published by Hwang et al. [23]. They reported that fucosterol obtained from the brown alga Sargassum fusiforme was observed to have anti-photoaging properties. Fucosterol therapy decreased ultraviolet B (UVB)induced production of matrix metalloproteinase-1 (MMP-1), IL-6, p-c-Jun, and p-c-Fos and increased type I and transforming growth factor-1 (TGF-1) procollagen expression in normal human dermal fibroblast cells. In addition, fucosterol derived from Sargassum fusiforme was observed to regulate the expression of MMPs and type-I pro-collagen in UVirradiated HaCaT cells by modulating, microtubule associated protein kinase (MAPK) [45]. These findings suggest that fucosterol extracted from Sargassum fusiforme is a potential candidate for the prevention and treatment of skin aging.

\subsubsection{Hepatoprotective Effect}

The liver is the largest organ in the abdominal cavity and performs critical physiological functions. Acute liver failure is caused by liver injury, which is mainly caused by viral infections, drugs, food additives, alcohol, or radioactivity [46]. Fucosterol has a potent hepatoprotective effect by increasing GSH levels and decreasing ROS production, thereby preventing liver damage and increasing liver enzyme levels alanine aminotrans- 
ferase/ aspartate aminotransferase (ALT/AST) [47]. Fucosterol is a dual-LXR agonist that regulates the expression of key genes involved in cholesterol homeostasis in several cell lines without causing triglyceride accumulation in the liver $[48,49]$. In addition, a study by Mo et al. [50] showed that fucosterol can relieve acute liver injury induced by ConA by inhibiting P38 MAPK/PPAR $\gamma / \mathrm{NF}-\mathrm{kB}$ signaling, suggesting that fucosterol is a promising potential therapeutic agent for acute liver injury.

\subsubsection{Anti-Neurological Disease}

Neurological disorders are diseases of the nervous system, such as brain tumors, epilepsy, Parkinson's disease, stroke, and Alzheimer's disease (AD) [51]. In a study conducted by Yoon et al. [24], fucosterol extracted from Ecklonia cava subsp. stolonifera showed the presence of cholinesterase inhibitors against AchE and BchE. BChE was inhibited by fucosterol and 24-hydroperoxy 24-vinylcholesterol, with $\mathrm{IC}_{50}$ values of $421.72 \pm 1.43$ and $176.46 \pm 2.51 \mu \mathrm{M}$, respectively. The effect of the compound on amyloid-induced neurotoxicity can be used to determine the potential of the compound as an anti-AD [16,52]. Consequently, Padina australis-derived fucosterol reduced intracellular amyloid levels and increased neuroglobin mRNA expression in amyloid-induced SH-SY5Y cells [16]. Fucosterol extracted from Ecklonia cava subsp. stolonifera co-infusion attenuated cognitive impairment-induced $s A \beta_{1-42}$ in aging mice via the downregulation of GRP78 expression [52]. Furthermore, the anti-AD properties of fucosterol from macroalgae have also been reported by Jung et al. [53] and Wong et al. [54]. Research on effects of fucosterol against Parkinson's disease has been described by Paudel et al. [55], and it was found to exhibit a mild dopamine D4 antagonist effect by inhibiting the dopamine agonist effect by $32 \%$ at $100 \mu \mathrm{M}$. Furthermore, fucosterol extracted from Sargassum fusiforme has also been reported to inhibit epilepsy and act as an antidepressant. The group treated with $20 \mathrm{mg} / \mathrm{kg}$ fucosterol showed a significant increase in the hippocampal brain-derived neurotrophic factor (BDNF) levels $(p<0.05)$. Published studies show that fucosterol from marine algae can be an alternative compound for the treatment of neurological diseases.

\subsubsection{Antioxidant Activity}

Excessive ROS formation can trigger oxidative stress, which causes cell damage and changes cell functions. Antioxidants are required to maintain a balance and prevent negative effects from excessive ROS formation. Based on the literature reviewed, macroalgae showed antioxidant activity, which can be useful for preventing excessive ROS formation. Fucosterol from Sargassum fusiforme exhibited antioxidant properties by downregulating serum transaminase activity in $\mathrm{CCl}_{4}$-intoxicated rats. Sequentially, sGOT and sGPT activity decreased by $25.57 \%$ and $63.16 \%$, respectively. In addition, fucosterol treatment of CCl4-intoxicated rats also increased hepatic cytosolic SOD, catalase, and GSH-px [13]. Oktaviani et al. [56] reported that fucosterol from Hizikia fusiformis prolonged the lifespan of Caenorhabditis elegans (Nematoda). Based on these studies, fucosterols extracted from macroalgae are potential candidates for antioxidants that can be used in functional foods and medicines.

\subsubsection{Antimicrobial Activity}

Antimicrobial activities can be defined as the process of inhibiting or destroying the growth of microorganisms, especially pathogenic microorganisms. The antimicrobial properties, including antibacterial and antifungal properties of marine macroalgae, are associated with various groups of bioactive lipids, such as fucosterol. The results of the study by Tyskiewicz et al. [57] showed that fucosterol from Fucus vesiculosus at a concentration of $1.0 \%$ completely inhibited the germination of macroconidia in Fusarium culmorum (Fungi, Ascomycota). Furthermore, when macroconidia were exposed to low doses of fucosterol (0.05-0.2\%), their growth was inhibited, and structural degradation occurred. Furthermore, fucosterol from Sargassum carpophyllum cultured with Pyricularia oryzae (Fungi, Ascomycota) mycelia caused abnormal morphological changes [22]. Previous 
studies confirmed the antibacterial and antifungal activity of 3,6,17-trihydroxy-stigmasta4,7,24(28)-triene, fucosterol, and 14,15,18,20-diepoxyturbinarin compounds from Turbinaria conoides, with MICs ranging from 2 to $16 \mu \mathrm{g} / \mathrm{mL}$, against Staphylococcus aureus, S. epidermidis, Escherichia coli, Pseudomonas aeruginosa, Aspergillus niger, and Candida albicans [58]. The antibacterial properties of Sargassum longifolium fucosterol were also tested against the human pathogen Vibrio parahaemolyticus and the fish pathogens $V$. vulnificus, $V$. harveyii, and Aeromonas hydrophililla. Interestingly, among these bacteria, only P. fluorescens was not susceptible to the effect of fucosterol [59]. Overall, fucosterol could potentially be a strong and promising antimicrobial agent.

\subsection{Safety and Toxicity of Fucosterol in Bacteria and Fungi}

Several studies on fucosterol in bacteria and fungi have been published $[22,57,58]$. From these articles, data extraction was performed, as shown in Table 1.

Table 1. Studies on safety and toxicity of fucosterol extracted from macroalgae, tested in bacteria and fungi.

\begin{tabular}{|c|c|c|c|c|c|c|}
\hline $\begin{array}{l}\text { Bacteria/ } \\
\text { Fungi }\end{array}$ & $\begin{array}{l}\text { Extract or } \\
\text { Chemical }\end{array}$ & Sources & Method & Concentration & Toxicity & Ref. \\
\hline Pyricularia oryzae & Fucosterol extract & $\begin{array}{c}\text { Sargassum } \\
\text { carpophyllum }\end{array}$ & Screening & $\mathrm{Nd}$ & $\begin{array}{l}\text { Affected the } \\
\text { morphology }\end{array}$ & [22] \\
\hline $\begin{array}{l}\text { Staphylococcus } \\
\text { epidermidis }\end{array}$ & Fucosterol extract & Turbinaria conoides & $\begin{array}{c}\text { Broth dilution } \\
\text { susceptibility assay }\end{array}$ & $2-256 \mu \mathrm{g} / \mathrm{mL}$ & $\begin{array}{l}\text { Inhibited bacteria } \\
\text { growth }\end{array}$ & [58] \\
\hline Aspergillus niger & Fucosterol extract & Turbinaria conoides & $\begin{array}{c}\text { Broth dilution } \\
\text { susceptibility assay }\end{array}$ & $2-256 \mu \mathrm{g} / \mathrm{mL}$ & $\begin{array}{l}\text { Inhibited } \\
\text { fungal growth }\end{array}$ & [58] \\
\hline Candida albicans & Fucosterol extract & Turbinaria conoides & $\begin{array}{c}\text { Broth dilution } \\
\text { susceptibility assay }\end{array}$ & $2-256 \mu \mathrm{g} / \mathrm{mL}$ & $\begin{array}{c}\text { Inhibited } \\
\text { fungal growth }\end{array}$ & [58] \\
\hline Escherichia coli & Fucosterol extract & Turbinaria conoides & $\begin{array}{c}\text { Broth dilution } \\
\text { susceptibility assay }\end{array}$ & $2-256 \mu \mathrm{g} / \mathrm{mL}$ & $\begin{array}{l}\text { Inhibited bacteria } \\
\text { growth }\end{array}$ & [58] \\
\hline $\begin{array}{c}\text { Staphylococcus } \\
\text { aureus }\end{array}$ & Fucosterol extract & Turbinaria conoides & $\begin{array}{c}\text { Broth dilution } \\
\text { susceptibility assay }\end{array}$ & $2-256 \mu \mathrm{g} / \mathrm{mL}$ & $\begin{array}{l}\text { Inhibited bacteria } \\
\text { growth }\end{array}$ & [58] \\
\hline $\begin{array}{l}\text { Pseudomonas } \\
\text { aeruginosa }\end{array}$ & Fucosterol extract & Turbinaria conoides & $\begin{array}{c}\text { Broth dilution } \\
\text { susceptibility assay }\end{array}$ & $2-256 \mu \mathrm{g} / \mathrm{mL}$ & $\begin{array}{l}\text { Inhibited bacteria } \\
\text { growth }\end{array}$ & [58] \\
\hline $\begin{array}{l}\text { Fusarium } \\
\text { culmorum }\end{array}$ & $\begin{array}{l}\text { Commercial } \\
\text { fucosterol }\end{array}$ & $\mathrm{Nd}$ & $\begin{array}{l}\text { Determined on a } \\
\text { liquid } R B \text { medium }\end{array}$ & $0.05-1.0 \%$ & $\begin{array}{l}\text { Inhibited } \\
\text { fungal growth } \\
\text { and caused } \\
\text { total degradation }\end{array}$ & [57] \\
\hline
\end{tabular}

Nd: not determined.

According to Tang et al. [58], fucosterol isolated from Sargassum carpophyllum showed low toxicity, with $\mathrm{IC}_{50}=250 \mu \mathrm{g} / \mathrm{mL}$, and was able to induce morphological changes in Pyricularia oryzae. Furthermore, fucosterol extract from Turbinaria conoides was used to test the level of growth inhibition in bacteria (S. aureus, S. epidermidis, E. coli, and P. Aeruginosa) and fungi (C. albicans and $A$. niger). In the tested bacteria, the MIC values ranged from 8 to $16 \mu \mathrm{g} / \mathrm{mL}$, which indicated that fucosterol was able to inhibit the growth of the tested bacteria well. In addition, fucosterol showed the highest growth inhibition in C. albicans, with MIC $=8 \mu \mathrm{g} / \mathrm{mL}$. Furthermore, research by Tyskiewicz et al. [57] showed that at a concentration of $1.0 \%$ fucosterol was able to optimally inhibit the growth of F. culmorum macroconidia. Moreover, macroconidia showed shorter length and structural degradation at lower fucosterol concentrations $(0.05-0.2 \%)$.

From these studies, we conclude that fucosterol can potentially be developed as a new agent for combating the problem of infection due to bacteria and fungi that are pathogenic because of its excellent biological activity as an inhibitor of bacteria and fungi. Based on our literature review, only the genera Turbinaria and Sargassum have been studied for the treatment of pathogenic bacteria and fungi. No other genera have been reported with respect to their safety and toxicity in bacteria and fungi. Further research on other bacteria and fungi species is required to comprehensively elucidate the safety and toxicity of fucosterol in bacteria and fungi. 


\subsection{Safety and Toxicity of Fucosterol in Cell Lines}

Several studies have demonstrated safety and toxicity in human cell lines $[17,27,28,35-$ $38,47,53,60-62]$ and animal cell lines $[15,42,43,45,54,55]$. The safety and toxicity of fucosterol in human and animal cell lines are summarized in Table 2.

Table 2. Studies on safety and toxicity of fucosterol extracted from macroalgae, tested in human and animal cell lines.

\begin{tabular}{|c|c|c|c|c|c|c|}
\hline Cell Lines & $\begin{array}{l}\text { Extract or } \\
\text { Chemical }\end{array}$ & Sources & Method & Concentration & Toxicity & Ref. \\
\hline $\begin{array}{c}\text { RAW } 264.7 \text { macrophage } \\
\text { cells }\end{array}$ & Fucosterol extract & Padina boryana & $\begin{array}{l}\text { MMT assay and } \\
\text { incubated for } 23 \mathrm{~h}\end{array}$ & $\begin{array}{l}12.5,25, \text { and } \\
50 \mu \mathrm{g} / \mathrm{mL}\end{array}$ & $\begin{array}{l}\text { Increased cell } \\
\text { viability }\end{array}$ & [43] \\
\hline $\begin{array}{l}\text { A549 human lung } \\
\text { epithelial cells } \\
\text { exposed to CPM }\end{array}$ & Fucosterol extract & $\begin{array}{c}\text { Sargassum } \\
\text { aquifolium (formerly } \\
\text { Sargassum binderi) }\end{array}$ & $\begin{array}{l}\text { MMT assay and } \\
\text { incubated for } 24 \mathrm{~h}\end{array}$ & $\begin{array}{c}3.125,6.25,12.5 \\
25,50, \text { and } \\
100 \mu \mathrm{g} / \mathrm{mL}\end{array}$ & $\begin{array}{l}\text { Low toxicity and } \\
\text { increased cell } \\
\text { viability }\end{array}$ & [44] \\
\hline $\begin{array}{l}\text { Chinese hamster ovary } \\
\text { (CHO) cells, rat } \\
\text { basophil leukemia } \\
\text { (RBL) cells, U373 cells, } \\
\text { and BA/F3 cells }\end{array}$ & Fucosterol extract & $\begin{array}{l}\text { Undaria pinnatifida } \\
\text { and Eisenia bicyclis }\end{array}$ & $\begin{array}{c}\text { Human } \\
\text { monoamine } \\
\text { oxidase ( } h \mathrm{MAO}) \\
\text { inhibition and } \\
\text { functional assay }\end{array}$ & $500 \mu \mathrm{M}$ & $\begin{array}{l}\text { Had no effects on } \\
\text { the viability of } \\
\text { the cells }\end{array}$ & [55] \\
\hline $\begin{array}{c}\text { Human dermal } \\
\text { fibroblasts (HDF) and } \\
\text { HaCaT cells }\end{array}$ & Fucosterol extract & $\begin{array}{c}\text { Sargassum } \\
\text { aquifolium (formerly } \\
\text { Sargassum binderi) }\end{array}$ & $\begin{array}{l}\text { MMT assay and } \\
\text { incubated for } 3 \mathrm{~h}\end{array}$ & $\begin{array}{c}3.125,6.25,12.5, \\
25,50, \text { and } \\
100 \mu \mathrm{g} / \mathrm{mL}\end{array}$ & $\begin{array}{l}\text { Not toxic and } \\
\text { increased cell } \\
\text { viability }\end{array}$ & [60] \\
\hline $\begin{array}{c}\text { Human recombinant } \\
\text { PTP1B }\end{array}$ & Fucosterol extract & Sargassum fusiforme & $\begin{array}{l}\text { Docking } \\
\text { simulation }\end{array}$ & 0 to $2 \mathrm{mM}$ & $\begin{array}{l}\text { Inhibited PTP1B } \\
\text { and } \\
\alpha \text {-glucosidase }\end{array}$ & [28] \\
\hline $\begin{array}{l}\text { RAW } 264.7 \\
\text { macrophages }\end{array}$ & Fucosterol extract & Undaria pinnatifida & $\begin{array}{l}\text { Western blot } \\
\text { analysis }\end{array}$ & 10,25, or $50 \mu \mathrm{M}$ & $\begin{array}{l}\text { Had no effects on } \\
\text { the viability of } \\
\text { the cells }\end{array}$ & [42] \\
\hline $\begin{array}{l}\text { Murine 3T3-L1 } \\
\text { preadipocytes }\end{array}$ & Fucosterol extract & $\begin{array}{l}\text { Ecklonia cava subsp. } \\
\text { stolonifera (formerly } \\
\text { Ecklonia stolonifera) }\end{array}$ & $\begin{array}{l}\text { Western blot } \\
\text { analysis }\end{array}$ & 25 and $50 \mu \mathrm{M}$ & $\begin{array}{l}\text { No significant } \\
\text { effects up to } \\
50 \mu \mathrm{M}\end{array}$ & [15] \\
\hline $\begin{array}{l}\beta \text {-Site amyloid } \\
\text { precursor protein } \\
\text { cleaving enzyme } 1 \\
\text { (BACE1) }\end{array}$ & Fucosterol extract & $\begin{array}{l}\text { Undaria pinnatifida } \\
\text { and Ecklonia cava } \\
\text { subsp. stolonifera } \\
\text { (formerly Ecklonia } \\
\text { stolonifera) }\end{array}$ & $\begin{array}{l}\text { Kinetics and } \\
\text { molecular } \\
\text { docking } \\
\text { simulation }\end{array}$ & $\begin{array}{l}0,5.0,20, \text { and } \\
100 \mu \mathrm{M}\end{array}$ & $\begin{array}{l}\text { Inhibited BACE1 } \\
\text { and not toxic }\end{array}$ & [53] \\
\hline $\begin{array}{l}\text { Insulin-resistant HepG2 } \\
\text { (human } \\
\text { hepatocarcinoma) cells }\end{array}$ & Fucosterol extract & $\begin{array}{l}\text { Ecklonia cava subsp. } \\
\text { stolonifera (formerly } \\
\text { Ecklonia stolonifera) }\end{array}$ & $\begin{array}{l}\text { MMT assay and } \\
\text { incubated for } 2 \mathrm{~h}\end{array}$ & $\begin{array}{l}12.5,25,50,100 \\
\text { and } 200 \mu \mathrm{M}\end{array}$ & $\begin{array}{l}\text { No significant } \\
\text { effect } \\
\text { up to } 100 \mu \mathrm{M}\end{array}$ & [27] \\
\hline $\begin{array}{l}\text { HepG2 cells induced } \\
\text { t-BHP and tacrine }\end{array}$ & Fucosterol extract & $\begin{array}{c}\text { Ecklonia cava subsp. } \\
\text { stolonifera (formerly } \\
\text { Ecklonia } \\
\text { stolonifera) and } \\
\text { Eisenia bicyclis }\end{array}$ & $\begin{array}{l}\text { MMT assay and } \\
\text { incubated for } 2 \mathrm{~h}\end{array}$ & $\begin{array}{l}0,25,50 \text { and } \\
100 \mu \mathrm{M}\end{array}$ & $\begin{array}{l}\text { Low toxicity and } \\
\text { increased cell } \\
\text { viability }\end{array}$ & [47] \\
\hline $\begin{array}{l}\mathrm{HaCaT} \text { cells induced } \\
\text { cobalt chloride }\left(\mathrm{CoCl}_{2}\right)\end{array}$ & Fucosterol extract & $\begin{array}{c}\text { Sargassum fusiforme } \\
\text { (formerly Hizikia } \\
\text { fusiformis) }\end{array}$ & $\begin{array}{l}\text { MMT assay and } \\
\text { incubated for } 2 \mathrm{~h}\end{array}$ & $1,2,5$, and $10 \mu \mathrm{M}$ & $\begin{array}{l}\text { Low toxicity and } \\
\text { increased cell } \\
\text { viability }\end{array}$ & [61] \\
\hline C8-B4 microglial cells & Fucosterol extract & Padina australis & $\begin{array}{l}\text { MMT assay and } \\
\text { incubated for } 4 \mathrm{~h}\end{array}$ & $\begin{array}{c}12,24,48,96, \text { and } \\
192 \mu \mathrm{M}\end{array}$ & $\begin{array}{l}\text { Had no effects on } \\
\text { the viability of } \\
\text { the cells }\end{array}$ & [54] \\
\hline $\begin{array}{c}\text { Colon carcinoma } \\
\text { (HT-29), colorectal } \\
\text { adenocarcinoma } \\
\text { (Caco-2), and breast } \\
\text { ductal carcinoma (T47D) } \\
\text { cell lines }\end{array}$ & Fucosterol extract & $\begin{array}{c}\text { Sargassum } \\
\text { angustifolium }\end{array}$ & $\begin{array}{l}\text { MMT assay and } \\
\text { incubated for } 4 \mathrm{~h}\end{array}$ & $\begin{array}{l}4.5,18,36, \text { and } \\
72 \mu \mathrm{g} / \mathrm{mL}\end{array}$ & Low toxicity & [38] \\
\hline $\begin{array}{l}\text { Oral carcinoma (KB), } \\
\text { epithelial carcinoma of } \\
\text { the larynx (Hep-2), } \\
\text { MCF-7, cervix } \\
\text { adenocarcinoma (SiHa), } \\
\text { and a human cell } \\
\text { embryonic kidney cell } \\
\text { line (HEK-293) }\end{array}$ & Fucosterol extract & $\begin{array}{c}\text { Dictyota ciliolata } \\
\text { Padina sanctae-crucis, } \\
\text { and Turbinaria } \\
\text { tricostata }\end{array}$ & $\begin{array}{l}\text { MMT assay and } \\
\text { incubated for } 2 \mathrm{~h}\end{array}$ & $\mathrm{Nd}$ & $\begin{array}{l}\text { Only inactive } \\
\text { on HEK-293 }\end{array}$ & [37] \\
\hline
\end{tabular}


Table 2. Cont.

\begin{tabular}{|c|c|c|c|c|c|c|}
\hline Cell Lines & $\begin{array}{l}\text { Extract or } \\
\text { Chemical }\end{array}$ & Sources & Method & Concentration & Toxicity & Ref. \\
\hline $\begin{array}{l}\text { Dalton's Lymphoma } \\
\text { Ascites (DLA) cells }\end{array}$ & Fucosterol extract & Turbinaria conoides & $\begin{array}{l}\text { Trypan blue } \\
\text { viability assay }\end{array}$ & $\begin{array}{c}100 \mathrm{and} \\
200 \mu \mathrm{g} / \mathrm{mL}\end{array}$ & Not toxic & [36] \\
\hline $\begin{array}{l}\text { Lung cancer cell and } \\
\text { human normal cell }\end{array}$ & $\begin{array}{l}\text { Commercial } \\
\text { fucosterol }\end{array}$ & $\mathrm{Nd}$ & $\begin{array}{l}\text { MMT assay and } \\
\text { incubated for } 24 \mathrm{~h}\end{array}$ & $\begin{array}{c}1.55,3.12,6.25 \\
12.5,25,50 \text {, and } \\
100 \mu \mathrm{g} / \mathrm{mL}\end{array}$ & $\begin{array}{l}\text { Decreased cell } \\
\text { viability in cancer } \\
\text { cell and low } \\
\text { toxicity in } \\
\text { normal cell }\end{array}$ & [17] \\
\hline $\begin{array}{l}\text { Human cancer cell lines } \\
\text { (HT29 and HCT116) } \\
\text { and CCD-18Co } \\
\text { fibroblasts }\end{array}$ & $\begin{array}{l}\text { Commercial } \\
\text { fucosterol }\end{array}$ & $\mathrm{Nd}$ & $\begin{array}{l}\text { MMT assay and } \\
\text { incubated for } 24 \mathrm{~h}\end{array}$ & 5 and $10 \mu \mathrm{M}$ & $\begin{array}{c}\text { Decreased cell } \\
\text { viability in HT29 } \\
\text { cells, but no effect } \\
\text { in HCT116 and } \\
\text { CCD-18Co }\end{array}$ & [62] \\
\hline $\begin{array}{l}\text { Human promyelocytic } \\
\text { leukemia cells (HL-60) }\end{array}$ & $\begin{array}{l}\text { Commercial } \\
\text { fucosterol }\end{array}$ & $\mathrm{Nd}$ & $\begin{array}{l}\text { MMT assay and } \\
\text { incubated for } 4 \mathrm{~h}\end{array}$ & $\begin{array}{l}7.55,15.1,30.2 \\
60.4, \text { and } \\
120.8 \mu \mathrm{M}\end{array}$ & Not toxic & [63] \\
\hline $\begin{array}{l}\text { Human ovarian cancer } \\
\text { (ES2 and OV90) cells }\end{array}$ & $\begin{array}{l}\text { Commercial } \\
\text { fucosterol }\end{array}$ & $\mathrm{Nd}$ & $\begin{array}{c}2^{\prime}, 7^{\prime}- \\
\text { dichlorofluorescin } \\
\text { diacetate assay }\end{array}$ & $\begin{array}{c}0,20,40,60,80 \\
\text { and } 100 \mu \mathrm{M}\end{array}$ & Not toxic & [35] \\
\hline $\begin{array}{l}\text { HaCaT cells and } \\
\text { monkey kidney } \\
\text { COS-7 cells }\end{array}$ & $\begin{array}{l}\text { Commercial } \\
\text { fucosterol }\end{array}$ & $\mathrm{Nd}$ & $\begin{array}{l}\text { MMT assay and } \\
\text { incubated for } 3 \mathrm{~h}\end{array}$ & $0.5,1$, and $5 \mu \mathrm{M}$ & $\begin{array}{l}\text { Had no effects on } \\
\text { the viability of } \\
\text { the cells }\end{array}$ & [45] \\
\hline
\end{tabular}

Nd: not determined.

In a study involving the use of commercial fucosterol for the treatment of RAW 264.7 macrophage cell line stimulated by particulate matter (PM), Jayawardena et al. [43] demonstrated the inhibition of $\mathrm{NO}$ production levels by observing inflammatory mediators, such as iNOS, COX-2, and pro-inflammatory cytokines (i.e., IL-6, interleukin-1 $\beta$ (IL-1 $\beta$ ), and tumor necrosis factor- $\alpha$ (TNF- $\alpha$ )), including prostaglandin E2 (PGE2)). Furthermore, the effect of fucosterol was amplified by the decreased expression of mitogen-activated protein kinase (MAPK) and NF- $\mathrm{BB}$ signaling pathway molecules and ROS regulation. Fernando et al. [44] showed that increasing concentrations $(>100 \mu \mathrm{g} / \mathrm{mL})$ of Chinese fine dust PM (CPM) in A549 cells significantly increased ROS levels and caused cell death. CPM-induced A549 cells treated with fucosterol of Sargassum aquifolium at a concentration of $3.125-50 \mu \mathrm{g} / \mathrm{mL}$ caused an increase in cell viability of up to $94.98 \pm 1.26 \%$, and the $\mathrm{IC}_{50}$ value was estimated to be $21.74 \pm 0.67 \mu \mathrm{g} / \mathrm{mL}$ [60]. In addition, Sargassum aquifoliumderived fucosterol was also reported to increase cell viability in HaCaT and HDF cells and yielded non-toxic results.

Another study reported that the addition of fucosterol isolated from Sargassum fusiforme in $\mathrm{HaCaT}$ cells induced by $500 \mu \mathrm{M} \mathrm{CoCl}_{2}$ increased cell viability up to $56 \%$ at a concentration of $10 \mu \mathrm{M}$ [61]. Furthermore, as reported by Choi et al. [47], there was no effect on HepG2 cells after treatment with the crude extract of fucosterol up to a concentration of $100 \mu \mathrm{M}$. However, in HepG2 cells induced by t-BHP and tacrine, fucosterol showed low toxicity and increased cell viability. In addition, LPS-induced RAW 264.7 macrophages treated with fucosterol of Undaria pinnatifida showed an unclear toxic effect because the 3-(4, 5-dimethyl thiazole-2-yl)-2, 5-diphenyltetrazolium bromide MTT test results showed that fucosterol did not affect cell viability at a concentration of 10-50 $\mu \mathrm{M}$ [42]. These findings are similar to those of Wong et al. [54] at concentrations ranging from 12 to $192 \mu \mathrm{M}$, fucosterol of Padina australis did not have a significant cytotoxic effect on C8-B4 cells when compared with control (untreated cells) (approximately 100\% cell viability).

Research conducted by Paudel et al. [55] on activity of fucosterol from Undaria pinnatifida and Eisenia bicyclis reported that there was no visible effect of the crude fucosterol extract on MAO-A and MAO-B (half-maximal inhibitory concentration $\left(\mathrm{IC}_{50}\right)>500 \mu \mathrm{M}$ ). MAO is a catecholamine-degrading enzyme with a long-standing therapeutic profile; MAO-A and MAO-B are isoenzymes. In addition, the results of the functional assay showed that 
fucosterol did not show agonist activity at any of the receptors tested. Moreover, the crude extract of fucosterol can potentially inhibit PTP1B and $\alpha$-glucosidase with an $\mathrm{IC}_{50}$ value of $50.58 \pm 1.86 \mu \mathrm{M}$ [28], and BACE1 with an $\mathrm{IC}_{50}$ value of $64.12 \pm 1.0 \mu \mathrm{M}$ [53] without causing side effects.

In a report by Lee et al. [15], treatment with fucosterol from Ecklonia cava subsp. stolonifera of 3T3-L1 preadipocytes had no effect on inhibiting cell proliferation up to a concentration of $50 \mu \mathrm{M}$ [15]. This finding is complemented by previous investigations that stated that the survival of HepG2 cells was not affected up to a concentration of $100 \mu \mathrm{M}$ Ecklonia cava subsp. stolonifera-derived fucosterol for $24 \mathrm{~h}$. However, cell survival was reduced to $48 \mathrm{~h}$ at a concentration of $200 \mu \mathrm{M}$. Based on these results, they recommended that additional in vitro studies on the anti-diabetic activity of fucosterol be carried out using non-toxic concentrations of 50, 25, and $12.5 \mu \mathrm{M}$ [27].

The cytotoxicity of fucosterol in various human cancer cells has been widely published [17,62,64,65]. According to Mao et al. [17], commercial fucosterol inhibited the growth of all human lung cancer cells tested with $\mathrm{IC}_{50}$ values ranging from 15 to $60 \mu \mathrm{M}$. However, interestingly, fucosterol showed low toxicity in all normal cells with $\mathrm{IC}_{50}>100 \mu \mathrm{M}$, which indicated that fucosterol can selectively inhibit lung cancer cell growth, induce cell cycle arrest, and target the Raf/MEK/ERK signaling pathway. Other studies have shown that commercial fucosterol reduces cell viability and enhances the cytotoxic effect of 5-Fu in HT29 cancer cells without affecting normal colon fibroblasts (CCD-18Co). Studies on the toxicity of fucosterol on HL-60 [63]; ES2 and OV90 [35], HT-29, Caco-2, and T47D [38]; KB, Hep-2, MCF-7, and SiHa [37] yielded low to no toxicity results in DLA cells [36].

In previous studies, the safety and toxicity of fucosterol in human and animal cell lines have been extensively investigated. Most of the studies focused only on the brown seaweeds of genera Sargassum, Undaria, Turbinaria, and Ecklonia. Based on the literature reviewed, other genera, such as Ulva and Enteromorpha, have not been tested in cell lines. Fucosterol from these genera has been reported to have biological activity, but its safety and toxicity levels in cell lines have not been reported. Therefore, the mechanisms of other genera in cell lines should be investigated further.

\subsection{Safety and Toxicity of Fucosterol in Animals}

Several studies on the safety and toxicity of fucosterol isolated from marine macroalgae in animals have been published. The brown seaweed Ecklonia cava subsp. stolonifera [56,57] and Hizikia fusiformis or Sargassum fusiformis [31,34,56,66] were the most frequently discussed. A summary of the safety and toxicity of fucosterol in animals is presented in Table 3.

The research of Mo et al. [50], complements the data about the anti-diabetic and antiobesity properties of fucosterol that inhibits necrosis and apoptosis in a process mediated by PPAR $\gamma$ activation and inhibition of NF-B, which reduces inflammatory factors. Fucosterol also inhibits apoptosis and autophagy by upregulating Bcl-2 via PPAR $\gamma$, thereby decreasing functional Bax and Beclin-1. Park et al. [34] reported that administration of $200 \mathrm{mg} / \mathrm{kg}$ body weight to mice increased splenocyte proliferation and NO production without cytotoxicity. Based on the research by Oktaviani et al. [56], fucosterol from Sargassum fusiforme showed low toxicity because it significantly affected the survival of C. elegans (1.54-fold and 1.23-fold increase), at a concentration of $0.05 \mathrm{mg} / \mathrm{mL}$.

Some studies have been conducted to test the effect of fucosterol on the nervous system. Oh et al. [52] reported no toxicological response induced by the administration of fucosterol derived from Ecklonia stolonifera when it was injected at $10 \mathrm{~mol} / \mathrm{h}$ into the dorsal hippocampus for four weeks. After training of aging rats, there was an increase in latency to reach the platform. Furthermore, Zhen et al. [66] showed no neurotoxic effect at the same dose levels administered after 0.5 and $4 \mathrm{~h}$. Conversely, fucosterol from Sargassum fusiforme, showed no neurotoxic activity at the doses used in the forced or tail suspension tests $(10,20,30$, and $40 \mathrm{mg} / \mathrm{kg})$. Lee et al. [31] found that all doses of fucosterol from Sargassum fusiforme had no toxic effects in OVX mice. The results of the study showed that 
fucosterol treatment significantly improved the loss of bone density caused by ovariectomy. Furthermore, the research conducted by Choi et al. [47] showed that there were no deaths or gross appearance abnormalities, and no fucosterol-induced abnormal behavioral changes, seizures, or death over $24 \mathrm{~h}$ due to Ecklonia cava subsp. stolonifera and Eisenia bicyclis. However, pretreatment with fucosterol at doses of 25,50 , and $100 \mathrm{mg} / \mathrm{kg}$ body weight markedly attenuated this cytotoxic effect of tacrine. In addition, the hepatoprotective effect of fucosterol at the highest dose $(100 \mathrm{mg} / \mathrm{kg}$ body weight) resulted in serum ALT levels similar to those of the control group, suggesting that fucosterol has the potential to reduce tacrine-induced hepatotoxicity. The published results of fucosterol studies indicate that the number of in vivo tests involving algal metabolites is very limited. The experimental model that has been used thus far has focused on mice. Therefore, we propose that future research should focus on determining the full in vivo potency of fucosterol.

Table 3. Studies on safety and toxicity of fucosterol extracted from macroalgae, tested in animals.

\begin{tabular}{|c|c|c|c|c|c|c|}
\hline Animal & $\begin{array}{l}\text { Extract or } \\
\text { Chemical }\end{array}$ & Sources & Method & Concentration & Toxicity & Ref. \\
\hline E18 aging rats & Fucosterol extract & $\begin{array}{c}\text { Ecklonia cava } \\
\text { subsp. stolonifera }\end{array}$ & $\begin{array}{c}\text { Dorsal } \\
\text { hippocampus } \\
\text { injected by } \\
\text { fucosterol for } \\
4 \text { weeks }\end{array}$ & $10 \mu \mathrm{mol} / \mathrm{h}$ & $\begin{array}{l}\text { Increased the } \\
\text { latency to reach } \\
\text { the platform }\end{array}$ & [52] \\
\hline C57BL/ 6 mice & Fucosterol extract & $\begin{array}{l}\text { Sargassum } \\
\text { fusiforme }\end{array}$ & $\begin{array}{c}\text { Oral } \\
\text { administration }\end{array}$ & $\begin{array}{c}\text { 50,100, } \\
\text { and } 200 \mathrm{mg} / \mathrm{kg}\end{array}$ & $\begin{array}{l}\text { Increased splenocyte } \\
\text { proliferation and } \\
\text { increased NO } \\
\text { production with no } \\
\text { cytotoxicity }\end{array}$ & [34] \\
\hline Balb/e mice & Fucosterol extract & $\begin{array}{l}\text { Sargassum } \\
\text { fusiforme }\end{array}$ & $\begin{array}{l}\text { Administered by } \\
\text { via gastric } \\
\text { intubation route }\end{array}$ & $\begin{array}{l}0.1 \mathrm{~mL} / 20 \mathrm{~g} \\
\text { of mouse }\end{array}$ & Not neurotoxic & [66] \\
\hline $\begin{array}{l}\text { Ovariectomized } \\
(\text { OVX) rats }\end{array}$ & Fucosterol extract & $\begin{array}{l}\text { Sargassum } \\
\text { fusiforme }\end{array}$ & $\begin{array}{l}\text { Oral, for } 7 \text { weeks } \\
\text { beginning } \\
12 \text { weeks } \\
\text { post-operation }\end{array}$ & $\begin{array}{l}25,50, \text { and } \\
100 \mathrm{mg} / \mathrm{kg}\end{array}$ & Had no toxic effects & [31] \\
\hline $\begin{array}{c}\text { Caenorhabditis } \\
\text { elegans }\end{array}$ & Fucosterol extract & $\begin{array}{l}\text { Sargassum } \\
\text { fusiforme }\end{array}$ & $\begin{array}{l}\text { Measured on both } \\
\text { NGM agar and } \\
\text { broth containing } \\
\text { fucosterol }\end{array}$ & $\begin{array}{l}\text { Up to } 0.1 \mathrm{mg} / \mathrm{mL} \\
\text { in } 2 \% \text { dimethyl } \\
\text { sulfoxide (DMSO) }\end{array}$ & Low toxicity & [56] \\
\hline $\begin{array}{l}\text { Institute of } \\
\text { Cancer Research } \\
\text { (ICR) mice }\end{array}$ & Fucosterol extract & $\begin{array}{c}\text { Ecklonia cava } \\
\text { subsp. stolonifera } \\
\text { and Eisenia } \\
\text { bicyclis }\end{array}$ & $\begin{array}{c}\text { Oral, for } \\
3 \text { consecutive days }\end{array}$ & $\begin{array}{c}200 \mu \mathrm{L} \text { fucosterol } \\
(25,50, \text { and } \\
100 \mathrm{mg} / \mathrm{kg})\end{array}$ & No mortality & [47] \\
\hline $\begin{array}{l}\text { BALB/c mice } \\
\text { weighing }\end{array}$ & $\begin{array}{l}\text { Commercial } \\
\text { fucosterol }\end{array}$ & $\mathrm{Nd}$ & $\begin{array}{l}\text { Oral, administered } \\
\text { daily for } 3 \text { days }\end{array}$ & $\begin{array}{c}25,50, \text { or } \\
100 \mathrm{mg} / \mathrm{kg}\end{array}$ & $\begin{array}{c}\text { Inhibited } \\
\text { ConA-induced acute } \\
\text { liver injury } \\
\text { significantly }\end{array}$ & [50] \\
\hline
\end{tabular}

\section{Materials and Methods}

\subsection{Literature Search}

The preferred reporting items for systematic reviews and meta-analyses (PRISMA) method [67] were used for the collection, identification, screening, selection, and analysis of the studies reviewed. A literature search was performed using four databases: PubMed, Science Direct, Wiley, and Web of Science. The search criteria included scientific articles on fucosterol published between 2002 and 2020. The keywords used in the literature search were "fucosterol" and "bioactivites OR "biological activities" OR "safety" OR "toxicity" OR "characteristics" OR "structure" OR "cell lines" OR "microalgae" OR "macroalgae" OR "plant" OR "bacteria" OR "fungi" OR "invertebrates" OR "animals" OR "human." The total number of articles found was 1251, which, upon further screening by checking the title and keywords and removing similar articles, was decreased to 621. 


\subsection{Selection Criteria}

In the second screening stage, a total of 532 articles from the initial 621 articles were excluded after screening, based on in-depth observations of the abstract content of the articles. The second screening yielded 89 articles that met the criteria. Of the 89 articles, additional in-depth observations of the full text of all the articles were made. A total of 46 articles remained after this stage 3 screening. Upon completion of this final stage, a total of 38 publications and 5 additional articles through manual reference tracing were included in the final data collection and further analyzed. All stages of systematic screening of the articles are shown in Figure 6.

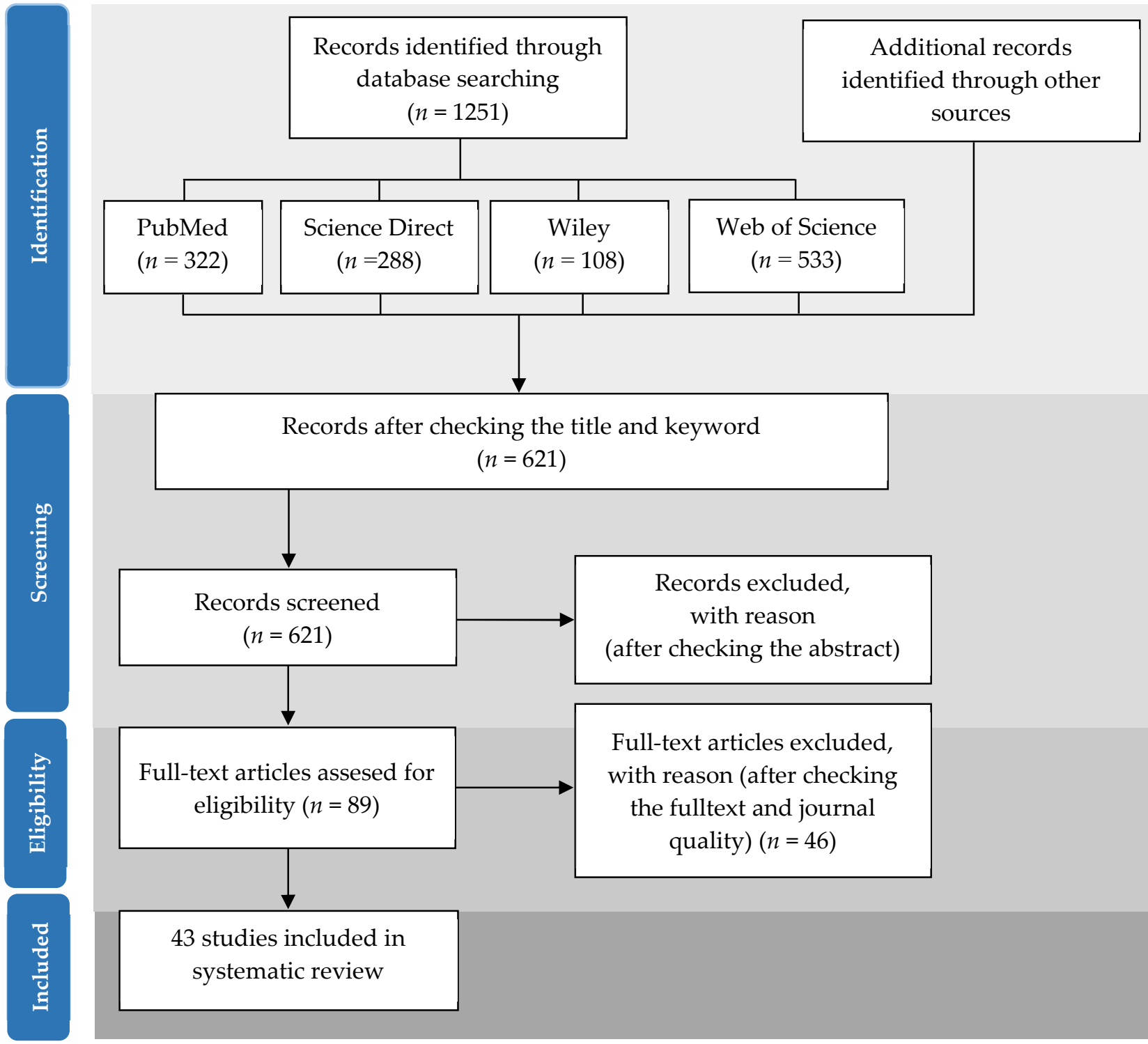

Figure 6. Summarized search method based on PRISMA.

\subsection{Data Extraction}

During the final selection, data were drawn from 43 studies on fucosterol. The data collection process was based on two main themes: (1) the characteristics of the articles, and (2) the criteria used to determine the bioactivity, safety, and toxicity of fucosterol. Specifically, the following features were extracted: year of publication, name of journal, geographic area where the research was conducted, author affiliation, publisher, biological 
activity of fucosterol, source of fucosterol, method used, experimental model, concentration of fucosterol, safety and toxicity of fucosterol.

\title{
4. Conclusions
}

Our review revealed that fucosterols derived from macroalgae can potentially be applied in the nutraceutical and pharmacological industries based on its bioactivities, safety, and toxicity. Fucosterol derived from brown macroalgae exhibits potentially beneficial activities; however, certain research gaps should be addressed. Despite the uncovered biological activities, most studies remain at a preliminary stage, and some of them have not included the study of safety and toxicity to organisms; hence, more in-depth studies are required. The studies of bioactivity, safety, and toxicity of fucosterol have been carried out mostly at the in vitro level (52\%), and only $26 \%$ have been conducted at the in vivo level using a mouse model. An in vivo experiment can provide fundamental data for understanding the mechanism of nutraceutical and pharmacological properties of sterol before it is used in clinical trials. However, we did not find any clinical studies on fucosterol published between 2002 and 2020. Studies on the safety and toxicity levels of fucosterol at the clinical stage are very important for the development of this sterol for the nutraceuticals and pharmaceutical industry. Brown macroalgae (Phaeophyta) are a major source of fucosterol. A total of 2071 species belonging to the class Phaeophyta have been recorded [68]. However, the study of fucosterol in brown macroalgae continues to be limited to only certain species. Hizikia fusiformis/Sargassum fusiforme and Ecklonia cava subsp. stolonifera are the two species with the highest number of publications. Additional studies on other Phaeophyta species are required to elucidate the fucosterol content in specific algal classes. Future comprehensive research on fucosterol, including the study of macroalgae sources, chemical characterization, pharmacokinetic mechanisms, in vitro, in vivo, and clinical experiments will elucidate the role of fucosterol as a potent bioactive compound derived from marine sources.

Author Contributions: Conceptualization, M.D.N.M., J.-S.K. and J.-S.C.; formal analysis, M.D.N.M., D.H., B.F.S.P.N. and G.T.; investigation, M.D.N.M., D.H., J.-S.C., B.F.S.P.N. and G.T.; methodology, M.D.N.M., J.-H.S. and J.-S.C.; software, D.H.; supervision, M.D.N.M., J.-S.K. and J.-S.C.; visualization, M.D.N.M., J.-H.S. and D.H.; writing—original draft, M.D.N.M. and D.H.; writing-review and editing, M.D.N.M. and J.-S.C. All authors have read and agreed to the published version of the manuscript.

Funding: This research was funded by the Ministry of Oceans and Fisheries, Korea, under the Project No. PJT200885 entitled: “Development and commercialization of traditional seafood products based on the Korean coastal marine resources".

Institutional Review Board Statement: Not applicable.

Data Availability Statement: Data supporting reported results are available upon request.

Conflicts of Interest: The authors declare no conflict of interest.

\begin{abstract}
Abbreviations
5-Fu, 5-fluorouracil; AchE, acetylcholinesterase; ALT, alanine aminotransferase; AR, aldose reductase; RLAR, rat lens aldose reductase; AST, aspartate aminotransferase; BACE1, $\beta$-secretase 1; BchE, butyrylcholinesterase; Bcl-2, B-cell lymphoma-2; ConA, concanavalin A; COX-2, cyclooxygenase-2; ERK, extracellular-signal-regulated kinase; EtOAc, ethyl acetate; FoxO, forkhead box protein O; GRP78, glucose regulatory protein 78; GSH, glutathione; GSH-px, glutathione peroxidase; HAB, harmful algal blooms; HDL, high density lipoprotein; HO-1, heme oxygenase-1; HRAR, human recombinant aldose reductase; $\mathrm{IC}_{50}$, half-maximal inhibitory concentration; IL-6, interleukin-6; IL-1 $\beta$, interleukin-1 $\beta$; iNOS, inducible nitric oxide synthase; LDL, low density lipoprotein; LPS, lipopolysaccharide; $\mathrm{LXR}$, liver $\mathrm{X}$ receptor; $\mathrm{MAO}$, monoamine oxidase; MAPK, microtubule associated protein kinase; MEK, mitogen-activated protein kinase; MIC, minimum inhibitory concentration; MMP-1, matrix metalloproteinase-1; MMPs, matrix metalloproteinases; mRNA, messenger RNA; MTT, (3-(4,
\end{abstract}


5-dimethyl thiazole-2-yl)-2, 5-diphenyltetrazolium bromide); mTOR, mammalian target of rapamycin; NF- $k \mathrm{~B}$, nuclear factor- $\kappa \mathrm{B}$; NGM, nematode growth medium; NO, nitric oxide; Nrf2, nuclear factor erythroid 2-related factor 2; P53, protein 53; p-c-Fos, phospho-c-Fos; p-c-Jun, phospho-c-Jun; PI3K/Akt, phosphatidylinositol 3-kinase/protein kinase B; PM, particulate matter; PPAR, proteins peroxisome proliferator-activated receptor; $\mathrm{PPAR} \gamma$, peroxisome proliferator- activated receptor gamma; PTP1B, protein tyrosine phosphatase 1B; Raf, mitogen-activated protein kinase; ROS, reactive oxygen species; sGOT, serum glutamic oxaloacetic transaminase; sGPT, serum glutamic pyruvic transaminase; SIRT1, sirtuin 1; SOD, superoxide dismutase; t-BHP, tert-butyl hydroperoxide; TGF-1, transforming growth factor-1; TLC, thin layer chromatography; TNF- $\alpha$, tumor necrosis factor alpha; UVB, ultraviolet B.

\section{References}

1. Hannan, M.A.; Sohag, A.A.M.; Dash, R.; Haque, M.N.; Mohibbullah, M.; Oktaviani, D.F.; Hossain, M.T.; Choi, H.J.; Moon, I.S. Phytosterols of marine algae: Insights into the potential health benefits and molecular pharmacology. Phytomedicine 2020, 69, 153201. [CrossRef]

2. Heilbron, I.; Phipers, R.F.; Wright, H.R. The chemistry of the algae. Part I. The algal sterol fucosterol. J. Chem. Soc. 1934, 1572-1576. [CrossRef]

3. Lopes, G.; Sousa, C.; Bernardo, J.; Andrade, P.B.; Valentão, P.; Ferreres, F.; Mouga, T. Sterol profiles in 18 macroalgae of the portuguese coast. J. Phycol. 2011, 47, 1210-1218. [CrossRef] [PubMed]

4. Saini, R.K.; Mahomoodally, M.F.; Sadeer, N.B.; Keum, Y.S.; Rengasamy, K.R. Characterization of nutritionally important lipophilic constituents from brown kelp Ecklonia radiata (C. Ag.) J. Agardh. Food Chem. 2021, 340, 127897. [CrossRef] [PubMed]

5. Sánchez-Machado, D.I.; López-Hernández, J.; Paseiro-Losada, P.; López-Cervantes, J. An HPLC method for the quantification of sterols in edible seaweeds. Biomed. Chromatogr. 2004, 18, 183-190. [CrossRef] [PubMed]

6. Terasaki, M.; Hirose, A.; Narayan, B.; Baba, Y.; Kawagoe, C.; Yasui, H.; Saga, N.; Hosokawa, M.; Miyashita, K. Evaluation of recoverable functional lipid components of several brown seaweeds (phaeophyta) from Japan with special reference to fucoxanthin and fucosterol contents1. J. Phycol. 2009, 45, 974-980. [CrossRef]

7. Kılınç, B.; Cirik, S.; Turan, G.; Tekogul, H.; Koru, E. Seaweed for Food and Industrial Application. In Food Industry; IntechOpen: London, UK, 2013; pp. 735-748.

8. McHugh, D.J. Seaweeds uses as Human Foods; Food and Agriculture Organization of United Nations: Rome, Italy, 2003; ISBN 92-5-104958-0.

9. Choi, J.S.; Seo, H.J.; Lee, Y.R.; Kwon, S.J.; Moon, S.H.; Park, S.M.; Sohn, J.H. Characteristics and in vitro anti-diabetic properties of the Korean rice wine, Makgeolli fermented with Laminaria japonica. Prev. Nutr. Food Sci. 2014, 19, 98-107. [CrossRef]

10. Choi, J.S.; Lee, K.; Lee, B.B.; Kim, Y.C.; Cho, K.K.; Choi, I.S. Safety, functionality and stability tests of Ecklonia cava extract for dermal application. Toxicol. Environ. Health Sci. 2014, 6, 61-66. [CrossRef]

11. Negara, B.F.S.P.; Sohn, J.H.; Kim, J.S.; Choi, J.S. Antifungal and larvicidal activities of phlorotannins from brown seaweeds. Mar. Drugs 2021, 19, 223. [CrossRef]

12. Khan, M.N.A.; Yoon, S.J.; Choi, J.S.; Park, N.G.; Lee, H.H.; Cho, J.Y.; Hong, Y.K. Anti-edema effects of brown seaweed (Undaria pinnatifida) extract on phorbol 12-myristate 13-Acetate-Induced mouse ear inflammation. Am. J. Chin. Med. 2009, 37, 373-381. [CrossRef]

13. Lee, S.; Yeon, S.L.; Sang, H.J.; Sam, S.K.; Kuk, H.S. Anti-oxidant activities of fucosterol from the marine algae Pelvetia siliquosa. Arch. Pharm. Res. 2003, 26, 719-722. [CrossRef]

14. Jung, H.A.; Jin, S.E.; Ahn, B.R.; Lee, C.M.; Choi, J.S. Anti-inflammatory activity of edible brown alga Eisenia bicyclis and its constituents fucosterol and phlorotannins in LPS-stimulated RAW264.7 macrophages. Food Chem. Toxicol. 2013, 59, 199-206. [CrossRef]

15. Lee, J.H.; Jung, H.A.; Kang, M.J.; Choi, J.S.; Kim, G. Do Fucosterol, isolated from Ecklonia stolonifera, inhibits adipogenesis through modulation of FoxO1 pathway in 3T3-L1 adipocytes. J. Pharm. Pharmacol. 2017, 69, 325-333. [CrossRef]

16. Gan, S.Y.; Wong, L.Z.; Wong, J.W.; Tan, E.L. Fucosterol exerts protection against amyloid $\beta$-induced neurotoxicity, reduces intracellular levels of amyloid $\beta$ and enhances the mRNA expression of neuroglobin in amyloid $\beta$-induced SH-SY5Y cells. Int. J. Biol. Macromol. 2019, 121, 207-213. [CrossRef]

17. Mao, Z.; Shen, X.; Dong, P.; Liu, G.; Pan, S.; Sun, X.; Hu, H.; Pan, L.; Huang, J. Fucosterol exerts antiproliferative effects on human lung cancer cells by inducing apoptosis, cell cycle arrest and targeting of Raf/MEK/ERK signalling pathway. Phytomedicine 2019, 61, 152809. [CrossRef] [PubMed]

18. Meinita, M.D.N.; Harwanto, D.; Sohn, J.H.; Kim, J.S.; Choi, J.S. Hizikia fusiformis: Pharmacological and Nutritional Properties. Foods 2021, 10, 1660. [CrossRef] [PubMed]

19. Negara, B.F.P.S.; Sohn, J.H.; Kim, J.S.; Choi, J.S. Effects of Phlorotannins on Organisms: Focus on the Safety, Toxicity, and Availability of Phlorotannins. Foods. 2021, 10, 452. [CrossRef] [PubMed]

20. Jung, H.A.; Islam, M.N.; Lee, C.M.; Oh, S.H.; Lee, S.; Jung, J.H.; Choi, J.S. Kinetics and molecular docking studies of an antidiabetic complication inhibitor fucosterol from edible brown algae Eisenia bicyclis and Ecklonia stolonifera. Chem. Biol. Interact. 2013, 206, 55-62. [CrossRef] 
21. Huh, G.W.; Lee, D.Y.; In, S.J.; Lee, D.G.; Park, S.Y.; Yi, T.H.; Kang, H.C.; Seo, W.D.; Baek, N.I. Fucosterols from Hizikia fusiformis and their proliferation activities on osteosarcoma-derived cell MG63. J. Korean Soc. Appl. Biol. Chem. 2012, 55, 551-555. [CrossRef]

22. Tang, H.F.; Yi, Y.H.; Yao, X.S.; Xu, Q.Z.; Zhang, S.Y.; Lin, H.W. Bioactive steroids from the brown alga Sargassum carpophyllum. J. Asian Nat. Prod. Res. 2002, 4, 95-101. [CrossRef]

23. Hwang, E.; Park, S.Y.; Sun, Z.W.; Shin, H.S.; Lee, D.G.; Yi, T.H. The Protective Effects of Fucosterol Against Skin Damage in UVB-Irradiated Human Dermal Fibroblasts. Mar. Biotechnol. 2014, 16, 361-370. [CrossRef]

24. Yoon, N.Y.; Chung, H.Y.; Kim, H.R.; Choi, J.S. Acetyl- and butyrylcholinesterase inhibitory activities of sterols and phlorotannins from Ecklonia stolonifera. Fish. Sci. 2008, 74, 200-207. [CrossRef]

25. Jung, H.A.; Jung, H.J.; Jeong, H.Y.; Kwon, H.J.; Kim, M.S.; Choi, J.S. Anti-adipogenic activity of the edible brown alga Ecklonia stolonifera and its constituent fucosterol in 3T3-L1 adipocytes. Arch. Pharm. Res. 2014, 37, 713-720. [CrossRef] [PubMed]

26. Bouzidi, N.; Viano, Y.; Ortalo-Magné, A.; Seridi, H.; Alliche, Z.; Daghbouche, Y.; Culioli, G.; El Hattab, M. Sterols from the brown alga Cystoseira foeniculacea: Degradation of fucosterol into saringosterol epimers. Arab. J. Chem. 2019, 12, 1474-1478. [CrossRef]

27. Jung, H.A.; Bhakta, H.K.; Min, B.S.; Choi, J.S. Fucosterol activates the insulin signaling pathway in insulin resistant HepG2 cells via inhibiting PTP1B. Arch. Pharm. Res. 2016, 39, 1454-1464. [CrossRef] [PubMed]

28. Seong, S.H.; Nguyen, D.H.; Wagle, A.; Woo, M.H.; Jung, H.A.; Choi, J.S. Experimental and Computational Study to Reveal the Potential of Non-Polar Constituents from Hizikia fusiformis as Dual Protein Tyrosine Phosphatase 1B and $\alpha$-Glucosidase Inhibitors. Mar. Drugs 2019, 17, 302. [CrossRef] [PubMed]

29. Lee, Y.S.; Shin, K.H.; Kim, B.K.; Lee, S. Anti-diabetic activities of fucosterol from Pelvetia siliquosa. Arch. Pharm. Res. 2004, 27, 1120-1122. [CrossRef]

30. Noureddin, M.; Mato, J.M.; Lu, S.C. Nonalcoholic fatty liver disease: Update on pathogenesis, diagnosis, treatment and the role of S-adenosylmethionine. Exp. Biol. Med. 2015, 240, 809-820. [CrossRef]

31. Lee, D.G.; Park, S.Y.; Chung, W.S.; Park, J.H.; Shin, H.S.; Hwang, E.; Kim, I.H.; Yi, T.H. The bone regenerative effects of fucosterol in in vitro and in vivo models of postmenopausal osteoporosis. Mol. Nutr. Food Res. 2014, 58, 1249-1257. [CrossRef]

32. Bang, M.H.; Kim, H.H.; Lee, D.Y.; Han, M.W.; Baek, Y.S.; Chung, D.K.; Baek, N.I. Anti-osteoporotic activities of fucosterol from sea mustard (Undaria pinnatifida). Food Sci. Biotechnol. 2011, 20, 343-347. [CrossRef]

33. Mayer, A.M.S.; Rodríguez, A.D.; Taglialatela-Scafati, O.; Fusetani, N. Marine pharmacology in 2009-2011: Marine compounds with antibacterial, antidiabetic, antifungal, anti-inflammatory, antiprotozoal, antituberculosis, and antiviral activities; affecting the immune and nervous systems, and other miscellaneous mechanisms of action. Mar. Drugs 2013, 11, 2510-2573. [CrossRef]

34. Park, S.; Hwang, E.; Shin, Y.; Lee, D.; Yang, J.; Park, J.; Yi, T. Immunostimulatory Effect of Enzyme-Modified Hizikia fusiforme in a Mouse Model In Vitro and Ex Vivo. Mar. Biotechnol. 2017, 19, 65-75. [CrossRef]

35. Bae, H.; Lee, J.Y.; Song, G.; Lim, W. Fucosterol suppresses the progression of human ovarian cancer by inducing mitochondrial dysfunction and endoplasmic reticulum stress. Mar. Drugs 2020, 18, 261. [CrossRef]

36. Kala, K.J.; Prashob Peter, K.J.; Chandramohanakumar, N. Cyto-toxic potential of fucosterol isolated from Turbinaria conoides against dalton's lymphoma ascites. Int. J. Pharmacogn. Phytochem. Res. 2015, 7, 1217-1221.

37. Caamal-Fuentes, E.; Moo-Puc, R.; Freile-Pelegrín, Y.; Robledo, D. Cytotoxic and antiproliferative constituents from Dictyota ciliolata, Padina sanctae-crucis and Turbinaria tricostata. Pharm. Biol. 2014, 52, 1244-1248. [CrossRef]

38. Khanavi, M.; Gheidarloo, R.; Sadati, N.; Shams Ardekani, M.R.; Bagher Nabavi, S.M.; Tavajohi, S.; Ostad, S.N. Cytotoxicity of fucosterol containing fraction of marine algae against breast and colon carcinoma cell line. Pharmacogn. Mag. 2012, 8, 60-64. [CrossRef]

39. Jiang, H.; Li, J.; Chen, A.; Li, Y.; Xia, M.; Guo, P.; Yao, S.; Chen, S. Fucosterol exhibits selective antitumor anticancer activity against hela human cervical cell line by inducing mitochondrial mediated apoptosis, cell cycle migration inhibition and downregulation of m-TOR/PI3K/Akt signalling pathway. Oncol. Lett. 2018, 15, 3458-3463. [CrossRef] [PubMed]

40. Prayong, P.; Barusrux, S.; Weerapreeyakul, N. Cytotoxic activity screening of some indigenous Thai plants. Fitoterapia 2008, 79, 598-601. [CrossRef] [PubMed]

41. Heo, S.J.; Yoon, W.J.; Kim, K.N.; Ahn, G.N.; Kang, S.M.; Kang, D.H.; Oh, C.; Jung, W.K.; Jeon, Y.J. Evaluation of anti-inflammatory effect of fucoxanthin isolated from brown algae in lipopolysaccharide-stimulated RAW 264.7 macrophages. Food Chem. Toxicol. 2010, 48, 2045-2051. [CrossRef] [PubMed]

42. Yoo, M.S.; Shin, J.S.; Choi, H.E.; Cho, Y.W.; Bang, M.H.; Baek, N.I.; Lee, K.T. Fucosterol isolated from Undaria pinnatifida inhibits lipopolysaccharide- induced production of nitric oxide and pro-inflammatory cytokines via the inactivation of nuclear factor- $\mathrm{kB}$ and p38 mitogen-activated protein kinase in RAW264.7 macrophages. Food Chem. 2012, 135, 967-975. [CrossRef] [PubMed]

43. Jayawardena, T.U.; Sanjeewa, K.K.A.; Lee, H.G.; Nagahawatta, D.P.; Yang, H.W.; Kang, M.C.; Jeon, Y.J. Particulate MatterInduced Inflammation/Oxidative Stress in Macrophages: Fucosterol from Padina boryana as a Potent Protector, Activated via NF-kB/MAPK Pathways and Nrf2/HO-1 Involvement. Mar. Drugs 2020, 18, 628. [CrossRef]

44. Fernando, I.P.S.; Jayawardena, T.U.; Kim, H.S.; Lee, W.W.; Vaas, A.P.J.P.; De Silva, H.I.C.; Abayaweera, G.S.; Nanayakkara, C.M.; Abeytunga, D.T.U.; Lee, D.S.; et al. Beijing urban particulate matter-induced injury and inflammation in human lung epithelial cells and the protective effects of fucosterol from Sargassum binderi (Sonder ex J. Agardh). Environ. Res. 2019, 172, 150-158. [CrossRef]

45. Kim, M.S.; Oh, G.H.; Kim, M.J.; Hwang, J.K. Fucosterol inhibits matrix metalloproteinase expression and promotes type-1 procollagen production in UVB-induced HaCaT cells. Photochem. Photobiol. 2013, 89, 911-918. [CrossRef]

46. Gossard, A.A.; Lindor, K.D. Autoimmune hepatitis: A review. J. Gastroenterol. 2012, 47, 498-503. [CrossRef] 
47. Choi, J.S.; Han, Y.R.; Byeon, J.S.; Choung, S.Y.; Sohn, H.S.; Jung, H.A. Protective effect of fucosterol isolated from the edible brown algae, Ecklonia stolonifera and Eisenia bicyclis, on tert-butyl hydroperoxide- and tacrine-induced HepG2 cell injury. J. Pharm. Pharmacol. 2015, 67, 1170-1178. [CrossRef]

48. Hoang, M.H.; Jia, Y.; Jun, H.J.; Lee, J.H.; Lee, B.Y.; Lee, S.J. Fucosterol is a selective liver X receptor modulator that regulates the expression of key genes in cholesterol homeostasis in macrophages, hepatocytes, and intestinal cells. J. Agric. Food Chem. 2012, 60, 11567-11575. [CrossRef]

49. Chen, Z.; Liu, J.; Fu, Z.; Ye, C.; Zhang, R.; Song, Y.; Zhang, Y.; Li, H.; Ying, H.; Liu, H. 24(S)-saringosterol from edible marine seaweed Sargassum fusiforme is a novel selective LXR $\beta$ agonist. J. Agric. Food Chem. 2014, 62, 6130-6137. [CrossRef] [PubMed]

50. Mo, W.; Wang, C.; Li, J.; Chen, K.; Xia, Y.; Li, S.; Xu, L.; Lu, X.; Wang, W.; Guo, C. Fucosterol protects against concanavalin a-induced acute liver injury: Focus on P38 MAPK/NF-k B pathway activity. Gastroenterol. Res. Pract. 2018, 2018. [CrossRef] [PubMed]

51. Ishwarya, M.; Narendhirakannan, R.T. The advances in neurobiology. Adv. Neurobiol. 2016, 12, 293-306. [CrossRef]

52. Oh, J.H.; Choi, J.S.; Nam, T.J. Fucosterol from an edible brown alga Ecklonia stolonifera prevents soluble amyloid beta-induced cognitive dysfunction in aging rats. Mar. Drugs 2018, 16, 368. [CrossRef] [PubMed]

53. Jung, H.A.; Ali, M.Y.; Choi, R.J.; Jeong, H.O.; Chung, H.Y.; Choi, J.S. Kinetics and molecular docking studies of fucosterol and fucoxanthin, BACE1 inhibitors from brown algae Undaria pinnatifida and Ecklonia stolonifera. Food Chem. Toxicol. 2016, 89, 104-111. [CrossRef]

54. Wong, C.H.; Gan, S.Y.; Tan, S.C.; Gany, S.A.; Ying, T.; Gray, A.I.; Igoli, J.; Chan, E.W.L.; Phang, S.M. Fucosterol inhibits the cholinesterase activities and reduces the release of pro-inflammatory mediators in lipopolysaccharide and amyloid-induced microglial cells. J. Appl. Phycol. 2018, 30, 3261-3270. [CrossRef]

55. Paudel, P.; Seong, S.H.; Jung, H.A.; Choi, J.S. Characterizing fucoxanthin as a selective dopamine D3/D4 receptor agonist: Relevance to Parkinson's disease. Chem. Biol. Interact. 2019, 310, 1-8. [CrossRef] [PubMed]

56. Oktaviani, D.F.; Bae, Y.; Dyah, M.; Meinita, N.; Moon, I.S. An Ethanol Extract of the Brown Seaweed Hizikia fusiformis and Its Active Constituent, Fucosterol, Extend the Lifespan of the Nematode Caenorhabditis elegans. J. Life Sci. 2019, 29, $1120-1125$. [CrossRef]

57. Tyskiewicz, K.; Tyskiewicz, R.; Konkol, M.; Rój, E.; Jaroszuk-Sciseł, J.; Skalicka-Wozniak, K. Antifungal Properties of Fucus vesiculosus L. Supercritical Fluid Extract against Fusarium culmorum and Fusarium oxysporum. Molecules 2019, 24, 3518. [CrossRef]

58. Kumar, S.S.; Kumar, Y.; Khan, M.S.Y.; Gupta, V. New antifungal steroids from Turbinaria conoides (J. Agardh) Kutzing. Nat. Prod. Res. 2010, 24, 1481-1487. [CrossRef]

59. Rajendran, I.; Chakraborty, K.; Pananghat, V. Bioactive sterols from the brown alga Anthophycus longifolius (Turner) Kützing, 1849 (= Sargassum longifolium). Indian J. Fish. 2013, 60, 83-86.

60. Fernando, I.P.S.; Jayawardena, T.U.; Kim, H.S.; Vaas, A.P.J.P.; De Silva, H.I.C.; Nanayakkara, C.M.; Abeytunga, D.T.U.; Lee, W.W.; Ahn, G.; Lee, D.S.; et al. A keratinocyte and integrated fibroblast culture model for studying particulate matter-induced skin lesions and therapeutic intervention of fucosterol. Life Sci. 2019, 233, 116714. [CrossRef]

61. Sun, Z.; Mohamed, M.A.A.; Park, S.Y.; Yi, T.H. Fucosterol protects cobalt chloride induced inflammation by the inhibition of hypoxia-inducible factor through PI3K/Akt pathway. Int. Immunopharmacol. 2015, 29, 642-647. [CrossRef]

62. Ramos, A.A.; Almeida, T.; Lima, B.; Rocha, E. Cytotoxic activity of the seaweed compound fucosterol, alone and in combination with 5-fluorouracil, in colon cells using 2D and 3D culturing. J. Toxicol. Environ. Heal.-Part A Curr. Issues 2019, 82, 537-549. [CrossRef]

63. Ji, Y.B.; Ji, C.F.; Yue, L. Study on human promyelocytic leukemia HL-60 cells apoptosis induced by fucosterol. Biomed. Mater. Eng. 2014, 24, 845-851. [CrossRef]

64. Malhão, F.; Ramos, A.A.; Rocha, E. Cytotoxic and Anti-Proliferative Effects of Fucosterol, Alone and in Combination with Doxorubicin, in 2D and 3D Cultures of Triple-Negative Breast Cancer Cells. Med. Sci. Forum 2021, 2, 8600. [CrossRef]

65. Pacheco, B.S.; dos Santos, M.A.Z.; Schultze, E.; Martins, R.M.; Lund, R.G.; Seixas, F.K.; Colepicolo, P.; Collares, T.; Paula, F.R.; De Pereira, C.M.P. Cytotoxic activity of fatty acids from Antarctic macroalgae on the growth of human breast cancer cells. Front. Bioeng. Biotechnol. 2018, 6, 1-10. [CrossRef] [PubMed]

66. Zhen, X.H.; Quan, Y.C.; Jiang, H.Y.; Wen, Z.S.; Qu, Y.L.; Guan, L.P. Fucosterol, a sterol extracted from Sargassum fusiforme, shows antidepressant and anticonvulsant effects. Eur. J. Pharmacol. 2015, 768, 131-138. [CrossRef] [PubMed]

67. Moher, D.; Liberati, A.; Tetzlaff, J.; Altman, D.G.; Altman, D.; Antes, G.; Atkins, D.; Barbour, V.; Barrowman, N.; Berlin, J.A.; et al. Preferred reporting items for systematic reviews and meta-analyses: The PRISMA statement. PLoS Med. 2009, 6, e1000097. [CrossRef] [PubMed]

68. Guiry, M.D.; Guiry, G.M. AlgaeBase. World-Wide Electronic Publication; National University of Ireland: Galway, UK, 2021. Available online: http:/ / www.algaebase.org (accessed on 10 September 2021). 